University of Rhode Island

DigitalCommons@URI

Open Access Master's Theses

1987

\title{
An Assessment of Urban Neighborhood Dynamics: South Worcester, Worcester, Massachusetts
}

Sandy S. Conaty

University of Rhode Island

Follow this and additional works at: https://digitalcommons.uri.edu/theses

\section{Recommended Citation}

Conaty, Sandy S., "An Assessment of Urban Neighborhood Dynamics: South Worcester, Worcester, Massachusetts" (1987). Open Access Master's Theses. Paper 685.

https://digitalcommons.uri.edu/theses/685

This Thesis is brought to you for free and open access by DigitalCommons@URI. It has been accepted for inclusion in Open Access Master's Theses by an authorized administrator of DigitalCommons@URI. For more information, please contact digitalcommons-group@uri.edu. 


\section{AN ASSESSMENT OF URBAN}

HEIGHBORHOOD DYNAMICS:

SOUTH WORCESTER, WORCDSTER, MASSACHUSETTS

BY

SANDY S. CONATY

A RESEARCH PROJBCT SUBMITTED IN

PARTIAL FULFILIMENT OF THE REQUIRBMENTS

POR THE DEGREE AND MASTER OF

COMMUNITY PLANNING

UNIVERSITY OF RHODE ISILAND

1987 
MASTER OF COMMUNITY PLANNING

RESEARCH PROJECT

OF

SANDY S. CONATY

Approved:

Major Professor

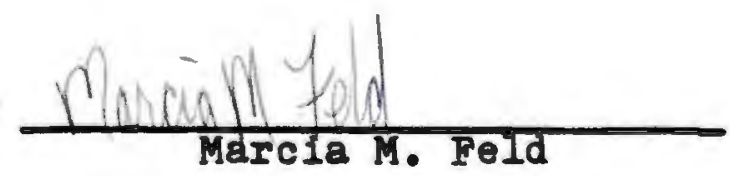

Acknowledged:

Director

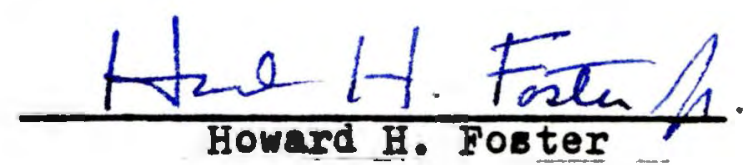




\section{ABSTRACT}

Urban dynamics are occurring in the neighborhood of South Worcester, Worcester, Massachusetts which are bringing changes to the residential environment of this neighborhood. Historically, South Worcester has been a working-class to lower-class stable residential veighborhood. It has had a significant industrial presence within its boundaries. Two developments during the 1960's, the 1963 zoning ordinance and the construction of Route 290, evoked changes in its residential environment, thereby threatening its residential stability. These external factors have impacted the housing values and the dynamics of change. They have promoted a shift frow the residential land uses to the non-residential land uses permitted under the manufacturing zoning classifications. As these land uses expand, there has been a decrease in the quality of the environwental characteristics resulting in a weakened desirability of this neighborhood as considered in locational decisions.

Several theories offer interpretations of urban neighborhood ohange dynamics. The application of key concepts from the "Arbitrage Model of Neighborhood Transition" completes the assessment of the dynamics in this South worcester neighborhood. Considerations of the arbitrage process, 
future expectations of households and its understanding of filtering demonstrate the process by which the residential ambience of the neighborhood has been weakened as the environment has been enhanced for expanding non-residential land usea. 


\section{ACKNOWIEDGEMLNTS}

The completion of this paper was possible with the direction of Dr. Marcia Feld. She had many helpful aggestions in pulling the paper together to maintain the continuity of the subject. She was available for me with many suggestions over the years it took to complete this research project.

The research for this paper was aided by the resources, knowledge and friendship of Dr. Charles Estus, Mr. Kevin Hickey, Dr. John McClymer and Dr. Kenneth Moynihan of Assumption College in Worcester, Massachusetts. Their Community Studies Program provided contacts to the South Worcester neighborhood and a compendium of data sources.

I would like to add a special thank you to a very special person, my husband Hank, for his patience in bearing with me while I completed this paper. It is finally done, Hank. 
TABIE OF CONTENTS

Abstract................................. p. i Acknowledgements............................. ir Table of Contents.......................... v

Iist of Tables............................ p. vi

Iist of Figures.......................... p. viii

INTRODUCTION.................................. 1

CHAPTER ONE Theories of Urban Dynamics............. p. 8

Neighborhood Succession and Filtering............. p. 13 Arbitrage Model of Neighborhood Transition......... p. 16 Orthodox Economic ("Economic Calculus").......... p. 23 Dual ("Social Calculus")....................... 28 Radical Theory................................ 31

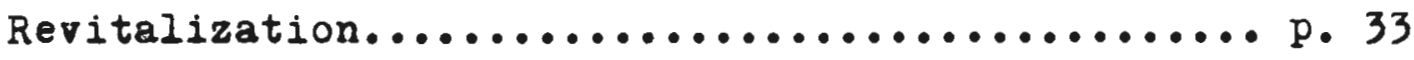

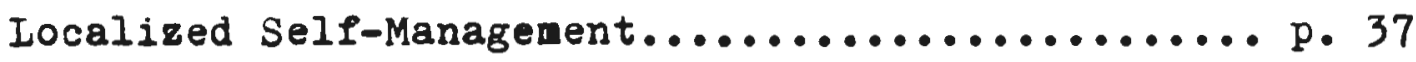

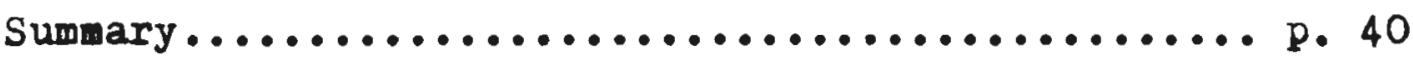
CHAPTER TWO The South Worcester Neighborbood........ p. 43

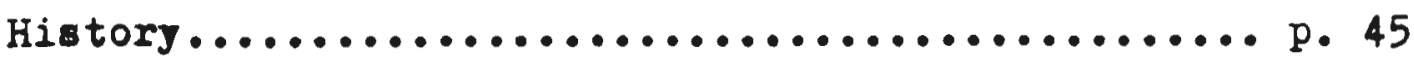
Analysis................................... 51

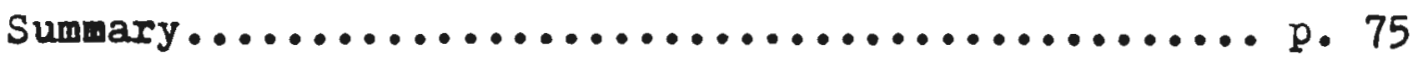
CHAPTER THREE Urban Dynamics in South Worcester..... p. 79 Zoning..................................... 81 Expressway Development......................... 98 


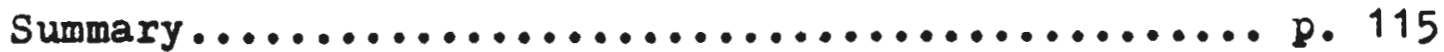
CHAPTER FOUR Assessment of Changes

in Soutb Worcester...................... 102

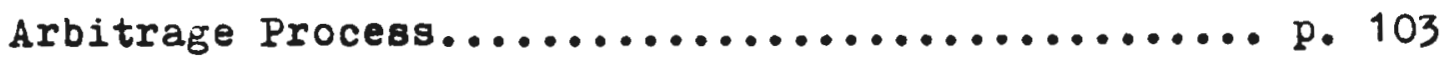

Future Expectations............................ 109

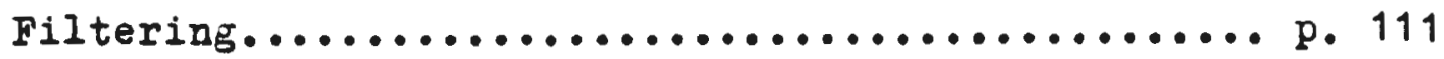

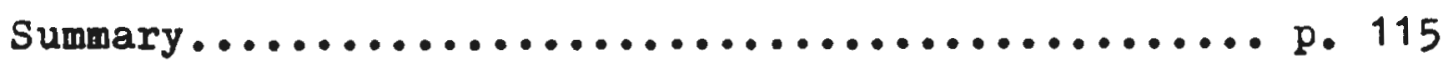

Bibliography............................. p. 117 


\section{IIST OP TABLES}

Table

Page

II-1 Indicators of Neighborhood Character....... 52

II-2 Demographic Characteristics for the

Population of South Worcester, 1980........59

II-3 Employed Fersons 16 Years and Over by

Occupation in Status Category, 1980........63

II-4 Household Distribution by Occupation for Worcester City and South worcester, 1979....64

II-5 Specified Renter-Occupied Housing Units by Household Income in 1979 by Gross Rent......66

II-6 Indicators of Neighbornood Stability for

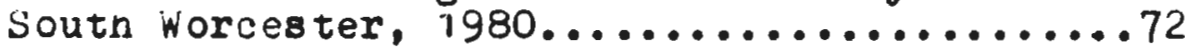




\section{IIST OF FIGURES}

Figure

II-1 City of Worcester,

South Worcester Neighborhood............46

II-2 Age Distribution by Percentage of Population for South Worcester, 1900........48

II-3 Land Use Mixture by Percentage of Use,

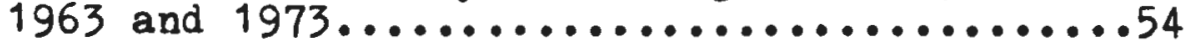

II-4 Population Cohort Chart for South Worcester, 1980.......................57

III-1 South Worcester Zoning Districts, 1951......83

III-2 South Worcester Zoning Districts, 1963......84

III-3 South Worcester Comparison Areas.........86 
An Assessment of Urban Neighborhood Dynanics: South Worcester, Worcester, Massachusetts

\section{INTRODUCTION}

Throughout wuch of the nineteenth century, American cities were divided into several virtually separate settlements. These distinct neigbborhood communities had only loose connections to each otber and to downtown. As a result, they developed as geographically contained, economically independent and institutionally cohesive neighborhoods. They were within the city's jurisdiction while not really being a part of the larger metropolitan whole. These neighborboods served as the primary focal point of urban life. 1

The passage of time brought many technological changes which influenced the development of these multinucleated urban centers. For instance, early advances in urban transportation systems made it possible to reside in one part of the city while maintaining jobs in other areas. With this easier access to the workplace, it was no longer necessary to be within walking distance of employment.

\footnotetext{
'Mark Goldman, "Buffalo's Black Rock: A Neighborhood
} and the City," in Neighborhoods in Urban America, ed. by Ronald H. Bayor (New York: National University Publications Kennikat Press, 1982), p. 52. 
This multinuclear urban system then evolved into an urban area with one center dominating the whole. One neighborhood area became the core of the city as it emerged to be the dominant geographical, economic, and political center of the city--the downtown area. With this transformation came several alterations to life within the urban area. The actual structure and institutions of the city changed so that these neighborhoods were no longer independent entities.

The result has been a change in "the way individuals live in and think about their neighborhood and their city." 2 City residents are now very mobile. They are able to choose from the entire city (and beyond) for work, a dentist and doctor, entertainment, shops to frequent, and friends with whom to socialize. There is such a wide choice and opportunity available in cities for these urban residents. This fluidity of use and choice has become the essence of cities and is oftentimes an underlying assumption for city cultural activities and special enterprises. 3 These events draw upon the skills, materials, customers and clientele available throughout the entire city.

Even though there is this extroversion to the city, it is not to say that the neighborhoods are not important to the urban residents. On the contrary, the conditions and

\footnotetext{
2 Ibid.

${ }^{3}$ Jane Jacobs, The Death and Iife of Great American Cities (New York: Random House, Inc., 1961), p. 116.
} 
various happenings within the neighborhood are indeed very important to neighborhood residents. ${ }^{4}$ They care about the atmosphere of the area in which they reside since it influences the kind of everyday life they lead. For this, the neighborhoods do not have to provide an artificial villagelike life. This type of self-containment is even detrimental to the neighborhood and to the residents by blocking the innate fluidity of use and choice and opportunities available in the city as a whole.

Neighborhoods need to provide safety for residents and for strangers in the vicinity. They are also instrumental to social contact in everyday life and the assimilation of children to city life and newcomers to the neighborhood and its way of life. This is possible with localized selfmanagement which is achieved through a system of very intricate, unconscious network of controls and standards in existence among residents which is enforced by these same people. 5 City neighbors may have nothing more in common than the sharing of this geographical area; however, if they fail to manage this area, the neighborhood will fail to provide them with the safety, social contact, and assimilation necessary to urban living. 6

A neighborhood which lacks this type of management is more apt to develop problems or have its existing problems

\footnotetext{
${ }^{4}$ Ibid., p. 117.

${ }^{5}$ Ibid., p. 32 .

${ }^{6}$ Ibid., p. 30 .
} 
accentuated to the point of being detrivental to the city as a whole. The city is influenced by the condition of the neighborhood since the various neighborhoods in a city are parts of the whole urban system. Taken together, they are the building blocks of which the city is composed. Since a city consists of many neighborhoods, the quality of these determines the quality of the city. If a neighborhood is experiencing difficulties, be they economic or social, this affects the city. A city which consists of neighborhoods that only draw from it and do not give something in return is unable to be a healthy city. ${ }^{7}$ Therefore, the welfare of a neighborhood is of great importance to a city. The quality of neighborhoods and the kind of life afforded in these neighborhoods is ever fluctuating. There are dynamics at work which lead to very subtle changes over long periods of time or very drastic changes in a relatively short time. Throughout modern times, neighborhoods have undergone these changes. A process of succession takes place and is always in progress in cities. With time, the homes in fashionable areas age. As their value decreases, they change hands falling to a lower income level. This is a pattern of slow decline with one time mansions becoming rooming-houses leading to eventual abandonment and demolition as they become unsafe.

7 James Feterson, "Revenues as Indicators of Neighborhood Stability," in Neighborhood in the Urban Economy, ed. by Benjamin Goldstein and Ross Davis (Lexington, MA: Lexington Books, 1977), p. 40. 
This succession process when followed through to the end (demolition of the structures) in Europe takes close to one hundred years. However, in the United States, the process is much quicker, taking half that time due to the available land at the outer limits of the cities. Advances in transportation technology making the workplace and economic centers more accessible, put additional stress on the quickness of this process. ${ }^{8}$

While this process has always been present, the transition was orderly and slow enough for urban housing markets to adjust. However, since the 1950's, there has been such an increase in the depletion of population in urban neighborhoods and the abandonment of property, that cities are lacking the time to make the necessary adjustments to assimilate to the process. ${ }^{9}$ By the time a change is made to absorb one change in a neighborhood, it is too late to accomplish any benefit.

The inability to adjust to change leads to wany problems which cities are now facing in their nelghborhoods. The 1950's accelerated the pace of a movement from the cities to the suburbs where more space is arailable for new home bullding. With this morement, cities are losing many families from their neighborhoods. These families have stable incomes with which they are able to buy new homes

\section{${ }^{8}$ Charles I. Leven, et al., Neighborhood Change:} Lessons in the Dynamics of Urban Decay (New York: Praeger Publishers, Inc., 1976), p. Xli. 
and commute to the workplace. The cities, therefore, are losing this income to the suburbs, outside of their taxing jurisdiction. Who is staying in the urban neighborhoods? Very often, they are the poor who cannot afford the cost of moving and the older persons who have strong emotional ties to their homes in the cities. This leaves the cities with a population which is weighted to the old and the poor. 10 There is a rising need for services and a decreasing ability to provide them. The result is a rise in social and fiscal problems which the city administrators must meet.

These problems have severe implications when planning for the city's future. Not only is the physical condition of urban neighborhoods affected, but the social fabric is also touched. Both of these elewents of neighborhood life are integral parts of the quality of life within it. City administrators and planners must aim to better the quality of life within these neighborhoods. Each neighborhood has problems which are unique to it and its dynamics. These neighborhood dynamics affect the urban housing warket through a fail or rise in property values which in turn influences the housing conditions. This then influences a population shift which affects the social network of the neighborhood. The quality of life of those living in the neighborhoods as these transitions take place also shifts, making adjustments necessary. Depending on the pace and the

${ }^{10}$ Ibid., p. xii. 
degree of change, the localized self-management mentioned earlier makes the necessary adjustments. However, if changes occur too rapidly for adjustments, the social fabric deteriorates and residents lose touch with the routines of their neighborhood. Uncertainty develops as residents wonder what the future will bring and what is bapponing to their neighborhood.

The focus of this paper is to assess the dynamics of change and consider the influence of city policy on this process in one urban neighborhood, South Worcester in Worcester, Massachusetts. In Chapter One, this paper considers various theories of neighborhood dynanics for an understanding of the process of change in urban neighborhoods. Chapter Two then considers South Worcester's history as a stable residential neighborhood and the current perception of it by city residents as a "deteriorating urban neighborhood." Chapter Three examines the impetus of the diminishing desirability of the residential environment in South Worcester. Finally, in light of these considerations, Chapter Four identifies which theory and concepts of neighborhood dynamics enhance the understanding of changes in this neighborhood. The future of Soutb Worcester is then considered should there be no change. 
CHAPTER I

THEORIES OF URBAN DYNAMICS

In an effort to achieve an understanding of urban neighborhood change, this chapter considers various theories of urban dynamics. Some are concerned with the process of decline while others consider the process of revitalization. Both decline and revitalization are integral parts of a neighborhood's life cycle. They can destroy the patterns of social contact in neighborhood life intricately developed by the neighborhood residents. The physical condition of a neighborhood's facilities does not necessarily indicate the welfare of the social network. Socially cohesive neighborhoods are able to exist amidst physically run-down structures while there are some physically well-kept neighborhoods with little or no social cohesion among the residents.

Underlying neighborhood change is the passage of time which ages the physical structures. Technical advances are made which can, in addition to the age of the structures, render buildings obsolete if not properly maintained. Modernization is required to update services and to enable structures to meet the various building codes. Howerer, some structures require too much work in time and money to make rehabilition economically feasible. These are 
removed to make way for newer facilities of a similar or of an alternate land use. Such subtle changes alter the functions of a neighborhood and its ability to meet the needs of its residents.

The households in a neighborhood are also affected by time. As they age, they go through various stages in their life cycle. Fach new stage raises new needs for the household. If the residents feel that the facilities in their present environment fulfill their household needs, they remain in the neighborhood. However, if it is their belief that these needs are not satisfied and can be met more efficiently elsewhere, they move. As the households move in and out of a neighborhood to find an environment to suit their needs, the social composition and networks change. This is a very general overview of how, over time, the functions and the social fabric of the urban neighborhood change. The various theories of urban dynamics delve more deeply into the processes of urban dynamics to search for the impetus of these changes. For example, Charles I. Leven, James T. Little, Hugh $O$. Nourse and R. B. Read in their studies of the St. Iouis area note that in the late $1960^{\prime}$ s and the 1970's solid middle-class neighborhoods were falling into decay and were being abandonned within one decade. ${ }^{1}$ They cited two patterns of change. In the

${ }^{1}$ Charles I. Leven, et al., Neighborhood Change, Lessons in the Dynamics of Urban Decay (New York: Praeger Publishers, Inc., 1976), p. 4. 
long-run, there was a decline in the central-city population and an increase in the population of the urban fringe which was accompanied by a general upgrading of the housing stock. In the short-range, the pattern of change was characterized by an increasing racial presence, a decreasing income level of the neighborhood, and depreciating ralues of the housing stock. Cases of extreme changes demonstrated that a rapid depreciation of the structures resulted in abandonment. While some of the units were not yet physically obsolete, the lack of maintenance due to the neighborhood change quickly rendered them $80 .^{2}$ Leven, Little, Nourse and Read concluded that the out-migration of the households and a weakening housing warket had possible connections to changes in the income and race of new residents. 3

To determine why there was such an out-migration of households and a weakening housing market, it was necessary to consider housing needs as more than the physical characteristics and condition of the unit itself. ${ }^{4}$ The urban environment is made up of several elements, namely the housing stock, congestion, noise, dirtiness, access to natural open space, recreational opportunity, transit, and activities. 5 The asount and condition of each of these

$$
\begin{aligned}
& 2_{\text {Ibid., p. }} 22 . \\
& { }^{3} \text { Ibid., p. } 11 . \\
& { }^{4} \text { Ibid., p. } 6 .
\end{aligned}
$$

${ }^{5}$ Dick Netzer, Economics and Urban Problems (2nd ed.; New York: Basic Books, Inc., T974), pp. 53-56. 
elements are factors which are considered in the locational decisions of households and enterprises. Therefore, housing as a concept must include the environeent surrounding the unit in addition to the characteristics of the unit.

Human ecology is one means of explaining the long-term "spatial organization and growth dynamics of urban communities." 6 A limited amount of land is available for the location of the many businesses, institutions, and households within a city. As components of the urban system, these groups are interdependent, one sector as producers of goods and services and the other as consumers of the goods and services. Therefore, all of these groups must be accomodated.

Competition between the land uses for space and among households for residential sites becomes the determinant of the spatial organization of cities. ${ }^{7}$ Each use has varying locational needs. When the needs of these uses overlap, competition occurs. According to the principle of dominance, the most economically powerful groups and institutions "win" the better land. Generally the industrial and large commercial concerns are the most powerful. They also have more specific land needs which increase their determination. Therefore, they are usually located in the

${ }^{6}$ Dennis E. Poplin, Communities: A Survey of Theories and Methods of Research (2nd ed.; New York: MacMillan Publillan Publishing Co., Inc., 1979), p. 83.

7 Ibid., p. 89. 
center of cities or where main transportation routes intersect to increase their market capacity and their accessibility. 8

The remaining land is allocated among residential users. Using the same principle of dominance, the allocation of land among residential users becomes a competition between the various socioeconomic groups. As a result, the most economically powerful groups reside in the less congested, more preferable land at the outer limits of the city. The least economically powerful groups reside in the least desirable land, that closest to the industrially-congested areas. Other groups compete for the land between these extremes.

The more immediate factors of spatial organization and growth dynamics are the locational decisions of the households and businesses as they search for space in the urban community. The decision-making process is an exercise in maximizing satisfaction or utility while minimizing costs. Households and businesses seek to maximize the quality of the unit and its location. The quality of the structure, its environment, access to employment opportunities and those people and activities with which contact is frequent are considered. 9 The greater the time, energy and money attributed to travel costs, the lower demand is for the site. Prestige and environmental damages, while more

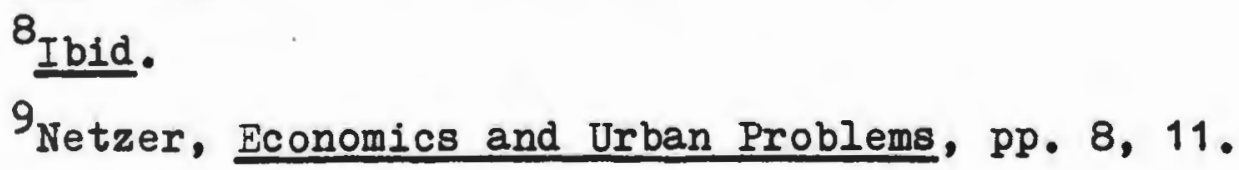


subjective, are also considered in the locational decision. The theories which follow consider the neighborhood dynamics which lead to changes in the elements of locational decisions discussed above and alter the identity of the neighborhood. Each theory offers greater understanding to the process of change in urban neighborhoods.

NEIGHBORHOOD SUCCESSION AND FIITERING

The notion of succession has its origins in the human ecology of Burgess, Park and McKenzie discussed earlier. ${ }^{10}$ Neighborhoods have a natural life cycle characterized by the occupancy of a succession of demographic groups. As time passes, the income-levels of the resident population decreases as the age of the neighborhood increases. The same process occurs with the individual dwelling unit. According to this school of thought, cities grow in concentric rings. Growth is a function of a changing population and a rising income. With the aging of these rings, there is a succession of occupancy. The character of the succession depends largely on the changes in the occupants and in the age and income distribution. Holding income constant, each of the rings is subject to a cycle of occupancy involving households of ever lower-income. This process is a result of the depreciation of the value of housing structures with age. As the dwelling unit ages, it has less to offer for housing services as compared to new ${ }^{10}$ Leven, et al., Neighborhood Change, p. 26. 
construction. Demand for housing is directly related to the income of tine household; therefore depreciation of tine dwelling unit with age leads to lower-income occupancy. Since these beginnings of the theory, several factors have been expanded with further consideration. Homer Hoyt viewed the growth patterns in sectors or wedges emanating from a center area. ${ }^{11}$ Growth occurs at the outer edge of the sector with new construction. A succession process follows within the sector. Hoyt considered housing values as a function of the socioeconomic level of the residents within a neighborhood.

Filtering is a result of an increase in demand for housing as incomes rise and as the value of a dwelling unit decreases with age. Richard Ratcliffe believed in a social value in this filtering process. ${ }^{12}$ New construction releases existing housing to the filtering process. This offers an improved dwelling to all households in the subsequent market shift. Ira Lowry contends that improvements of a structural nature that would extend the life of a housing unit is a function of income. Maintenance of this nature is expensive and lower income families cannot afford to invest in their dwelling unit. Therefore, the improvement in the quality of dwelling unit is temporary. Since upkeep is not easily affordable to the lower income households, the house

$$
\begin{aligned}
& 11 \text { Ibid., p. } 27 . \\
& 12_{\text {Ibid. }}
\end{aligned}
$$


continues to depreciate and deteriorate.

The concept of external influences on property values was explored by Hurd. The type and condition of land uses adjacent to the property are determining factors of housing prices. ${ }^{13}$ As externalities, they influence the value of a unit as perceived by a household. The availability of local goods and services that the household consumes also influences the locational decision.

Martin Bailey delved more deeply into the influence of neignborhood effects on the housing values. ${ }^{14}$ In his studies of residential segregation, he considers particular population groups as a nuisance. Households consider it to be unpleasant to live near those it feels have undesirable characteristics as considered in terms of race, income, or ethnicity. Some values of these characteristics are considered to be positive traits. Households attempt to live near those they attribute with the positive characteristics while they wish to live separate from those with the negative traits. Households characterized by the positive traits living near those who are not, suffer a discount in their property values. On the other hand, those without the "desirable" traits living near those with them receive a premium added to their property values. 15

$$
\begin{aligned}
& 13 \text { Ibid., p. } 29 . \\
& 14 \text { Ibid. } \\
& { }^{15} \text { Ibid., p. } 30 .
\end{aligned}
$$


ARBITRAGE MODEI OF NEIGHBORHOOD TRANSITION

Leven, Iittle, Nourse and Read built on the hypotheses of succession and filtering in their arbitrage model. 16 This model is concerned extensively with the effect that the various external factors in and around a neighborhood have on the housing values and dynamics. They synthesized hypotheses of succession and filtering and Martin Bailey's model of residential segregation in their model with the thesis that households have preferences over what they call housing bundles or characteristics. These characteristics are not limited to the physical structure itself. They also include the characteristics of the neighborhood populations. The arbitrage model is also an extension of the succession and filtering theories. It seeks to explain the various patterns of income segregation as well as the racial segregation experienced by 80 many neighborhoods. The dynamics of the housing market, contends the theory, can be understood through the land uses, neighborhood population, public service, and access characteristics; not simply the physical quality and characteristics of the housing units. The uncertainty of how the future will affect these characteristics is also significant to the housing decision. It is a fundamental element in the understanding of housing market dynamics.

When a household buys or rents a dwelling unit, not

${ }^{16}$ Ibid., pp. 34-49. 
only has it received the use of the unit, but it has also purchased the physical characteristics, public services, access to the area shops, jobs, recreation facilities as well as other neighborhood facilities and land uses. The socioeconomic characteristics of the neighbors and their housing are also part of this purchase. Together these elements comprise the neighborhood quality and are considered as the bundle of the characteristics of the property. A household places a value on its dwelling unit according to its preferences in terms of these collective physical and neighborhood characteristics. The price a household is willing to pay for a unit then depends on the desirability of its "housing bundle." 17 This is the value of the property taken in terms of future status of th property characteristics.

When considering a move, a household decides how much more or less than the present value of its housing bundle it can afford. Only when this is achievable is there mobility within the market. A household is motivated to move if the amount the household is willing or able to pay for a housing bundle is altered. This occurs if the size or composition of the family changes or if the household income either increases or decreases. Households also consider a move if they are able to purchase a different housing bundle for a price that is beneficial in terms of perceived values

$$
17 \text { Ibid. . p. } 35 .
$$


of their existing housing bundle. As long as the household believes that it will benefit, it will consider a more.

In a competetive market, households act in a market arena within the parameters of their tastes and income level and the character of the housing supply which is best suited to these. There are many possible degrees of household income and varieties of tastes. Consequently, there are many interrelated submarkets based on the characteristics of units and patterns of neighborhood housing bundles. Households rank the housing units according to their preferences for its particular characteristic mix. Therefore, a unit's desirability depends on the preference of the households for its housing bundle. The unit's price in the market is reflective of its particular preference rank to a household.

The arbitrage process of this model is the mechanism by which the housing supply moves from one submarket to another. This process occurs in one of two ways. The supply shifts as households move from one neighborhood to another or by a change in the housing bundle to such a degree that it serves a new and different clientele. A small number of households who move for unrelated reasons could influence a larger movement. The effect which the replacement households have on the neighborhood character and the local services could alter the perceptions of remaining households. If the perceptions are not to their liking, the remalning households then decide to move from 
the neighborbood. Changes of this nature tend to be focused on a few neighborhoods and may lead to a rather rapid turnover and price change.

The character of a neighborhood is reflective of its residents. Any change that occurs in the neighborhood's social, economic or racial composition alters the housing bundle that the neighborhood offers. This also changes the preference rank of the units in the neighborhood as well. Due to this, there is a change in occupancy and in prices of the units.

Since households make locational decisions using future expectations of values of their property, expected changes in housing bundles can alter the preference rank of the housing in a neighborhood. Shifts in the preference ranking would lead to changes in occupancy and prices in a neighborhood. Households are continuously reassessing the value of their property based on expectations of the future status of the property characteristics. The households consider the likelihood or nonlikelihood that the housing bundle may change. These estimates of future property value are made in a very uncertain environment. Therefore, the households are very sensitive to changes they perceive as a sign of change in the neighborhood. krternal erents nay suggest an upcoming change in the housing bundle. For example, new housing or commercial developments or shifts in local government policy can alter the expected bundle. 
The structural characteristics and the locational attributes of the housing bundle are considered in the estimates of future property values. Ascertaining the future valus in terms of soundness and modernity of the structure as well as other structural traits is fairly easy. However, the future locational attributes are not as predictable. There is much more uncertainty involved with the neighborhood characteristics. Access and local government are more slow to change; but, such elements as the income level and racial composition can change quickly. Households are extremely sensitive to trends and developments in any of these features which may alter the housing bundle.

Banks and financial institutions who finance home purchases consider the expectations of the future characteristics of the piece of property. Their assessment of the future values influences the market. Low estimates of future values lead to more restrictive terms in lending such as large down-payments, short-term loans and stronger assurances of the financial soundness of the borrower. Eventually, through red-lining, they may close a neighborhood completely for financial assistance. They may believe the risk to be too great for the expected future values. The result of this is an inability to sell property in the neighborhood, except through owner-financed mortgages. Units vacant for long periods of time fall prey to vandalism. Eventually, with the decline, the value of the housing reaches zero. 
The filtering process in other theories is experienced within the dwelling unit. In this model, the welfare of a household is connected to their preferences. As long as the householas reel that they are better oII, there has been a welfare benefit. Therefore, the household, not the dwelling unit, is the active participant in the filtering process. Filtering takes place when "a household, without a change in its income or tastes, experiences a change in its housing bundle to a different rank on its scale of preferences."18 A household conceivably can "filter up" to a more preferred housing bundle or "filter down" to a less desirable bundle. This conception of filtering implies that the process can occur even if the household does not move. Therefore, there can be both an active filtering process or a passive filtering process. Active filtering occurs when the household makes a locational change to a different housing bundle. However, the passive filtering is experienced without such a move. The housing bundle changes around the household. Externalities make the changes for the household.

This arbitrage model describes a very complex, yet Interdependent network that is at work within the urban system. The network may also be described as tenuous since much of the neighborhood dynamics rely on the tastes and preferences of households. When considering a move, a household looks at the available local public services and 18 Ibid., p. 46 . 
taxes which accompanies them, access to these facilities and to the workplace, as well as the characteristics of the other households in the neighborbood. Therefore, in addition to the traditional factors of housing (that is, the age of the structure, changing job locations and transportation access) the availability of public services and who is willing to live near whom and the influence of negative environmental influences are integral factors in the understanding of why neighborhoods change. ${ }^{19}$ Subtle shifts in the mixture of goods and services available, the cost of these in taxes and access, and in the social composition could alter the ambience of a neighborhood. Such changes in any of these factors can move the neighborhood into another phase of its life.

Arthur P. Solomon and Kerry D. Vandell consider the process of decline in urban neighborhoods in a different manner. They have developed three separate perspectives of decline in neighborhoods which are based on the motivation and behavior of landlords and tenants in their relationships with each other and the neighborhood. 20 The "Orthodox Economic Perspective" is purely economic in its viewpoint; the "Dual Theory" focuses primarily on the

$$
{ }^{19} \text { Ibid., p. } 6 .
$$

20 Arthur P. Solomon and Kerry D. Vandell, "Alternative Perspectives on Neighborhood Decline," Journal of the American Planning Association, XIVIII (Winter, 1982), 81-98. 
personal relationships between landlord and tenant; and, the "Radical Theory" is elitest oriented. While every neighborhood is different, Solomon and Vandell feel that they can be identified closely with one of their three perspectives.

OR:- HOLOX ECONOMIC ("ECONOMIC CALCULUS")

This theory is characterized by the economic concepts of an individual in the marketplace whose goal is to maximize his utility wile minimizing costs. The landlords are trying to maximize their profits in the marketplace. The relationship between the landlord and the tenant is governed by purely economic motivation. Relations are business-like with a formal lease and legal obligations for all parties.

Rent levels are set according to the market equilibrium at the intersection of supply and demand. Since the rental unit is a service provided by the landlord, the rent is set at a level to cover the fixed and variable costs of providing the unit and to provide a profit margin. This is the theoretical point where marginal costs equal marginal revenues. In other words, if the landlord set the rent at a higher level, he would not benefit from any additional rental income or revenue. Demand for the unit would decrease and the costs for providing the unit would increase due to fixed costs incurred while the unit is racant.

When the landlord chooses a tenant, the decision is based on the ability of the potential renter to pay. He 
also considers the wear and tear expected from the tenant. Other characteristics are not as important and often are not part of the decision. This rationale is consistent with the motivation of the owner to maximize his profit.

Considering the wear and tear a unit receives when occupied, upkeep is necessary to maintain standards. The extent of rehabilitation is dependent on the contribution of the work to future revenues. The landlord will rehabilitate as long as the marginal revenue from the work is expected to increase over the marginal costs of the work. Such a purely economical rationale is the basis of decisions regarding the improvements of property.

Financing for property eitier to purchase or to rehabilitate is from perfectly mobile capital. The owner searches out monies with the lowest costs attached to them, that is low-interest and leveraging factors. Ioans of this kind are taisen only when the marginal revenue expected is greater than the marginal costs attached to them.

The owner considers his property as an investment on which to make a profit. Investments in property return in three ways: 1) capital appreciation in the property, 2) tax shelters through deductions, and 3) a profit in cash flows. The process of decline begins when there is a lower expectation of returns. With the decline, the returns are shifted to the cash flow. The structure no longer appreciates in value and tax shelters are no longer available. Cash flows also decrease which brings further decline. This reduction 
is due to either a decreasing demand or to increasing costs of supplying the housing. in increase in vacancies is a usual sign of demand softening. To counter this, rents are often lowered to attract more income. Renter delinquencies are also encountered more often in this market decline. This reduces the cash flow further which initiates another downward spiral.

A decrease in demand can be due to more positive conditions outside of the area than in the neighborhood. These are "pull factors" which draw residents from the neighborhood to otner areas. Exampies of such positive externalities include newer housing wich is less functionally obsolete, industry moving out of the area taking jobs with it, and easier access to jobs and shopping facilities in other locations with the development of new transportation systems.

Negative internal conditions can be as detrimental to the demand for housing in a neighborhood. These are considered to be "push factors" which send residents looking for housing elsewhere. They include an increase in crime which diminishes the feeling of safety and well-being that may have once existed. Increases in air-pollution, an increase in non-conforming uses and other environmental degeneration can develop into such nuisances that residents feel their well-being is in jeopardy. This would be an additional reason for people to move to an area without such nuisances. Changes in the composition of the population 
to lower-income households or in the racial or ethnic make-up may influence an out-movement of the population as a reflection of whom is willing to live next to whom. Disinvestment in the neighborhood on the part of the city administration is also harmful, especially if residents believe the cuts in services in their neighborhood to be more severe than in other areas of the city. The resultant cut in services, such as schools, police, fire, or garbage collection may find households looking for better services els ewhere.

Reduced demand in a neignborhood due to any of the above factors results in a filtering process. This is a market response in hopes of increasing demand. Rents and unit prices decline making them affordable to a lower-income population and expanding the market.

An increase in the costs of supplying the housing service incurred by the landlords is another reason for a reduced cash flow. These increases in supply costs can be in any combination of areas. Maintenance and repair costs are some variable costs related to the aging of the unit, physical obsolescence, vandalism, a more rapid turn-over which requires more frequent refurbising, and an increase in thefts and assaults. With today's high fuel prices, costs to heat an older house with its high ceilings and limited insulation are higher. Fire and theft insurance are fixed costs which are also more costly for an older structure with its higher risk factor. In a nonappreciating market, property 
taxes can also be a high cost. These taxes may be higher than should be due to a lag in reassessment or an assessment which is based on what is considered to be the "highest and best use" for the property and not based on its actual use. rinally, there could be an increase in the cost of tinancing Ior the purchase or rehabilitation of such property. This may be the case aue to a perception of the financial institution that there is a higher risk of default connected with the property.

Any of the above demand or supply factors could initiate a decline with a reduction in returns on investment. Once a decline of this nature begins, it is difficult to interrupt it. The neighborhood becomes characterized by internal instabilities, and positive externalities outside of the neighborhood work to reinforce a lower demand for housing in the area and higher costs of supplying the service.

Once the income from the property is lowered, landlords respond by reducing their costs where possible. Inevitably the first areas of cost reduction are the variable costs of administration, management and maintenance and repairs. This leads to a downward cycle which eventually reaches a necessary cut in fixed costs such as insurance and taxes. If this continues, it leads to foreclosure, abandonment and eventually a demolishing of the structure.

Interaction of the supply and demand is very involved; it is very difficult, almost impossible to identify the initial cause of a decline once it is in progress. The 
result oftentimes is a policy intervention that attempts to be all encompassing. This spreads resources so thin that the effectiveness of the policy is hindered. Equally ineffective resources and programs may be so narrow in scope as to be directed at symptoms and not causes or only one aspect of the decline leaving others to operate.

\section{DUAI ("SOCIAI CALCULUS")}

Neignborhoods which can be classified according to this theory see a great duality in the landlord and tenant relationships. Motivation is more for pride in ownership and in one's surroundings in the neighborhood than for economic benefit. Therefore, the relationships tend to be interpersonal. This occurs since the landlord is usually a resident and is looking for compatibility with his tenants. Social contact in this arena develops more reciprocity. Instead of a formal lease, there is a negotiation of respective responsibilities. There are very few rent delinquencies. Since the property is treated well by tenants, there are also relatively few evictions.

It is possible for rent levels in these neighborhoods to be below the market level. The reciprocity of responsibilities allows for the lower rent levels. They are also possible since the landlord does not quantify the values for his time and efforts in upkeep. Opportunity costs do not receive consideration by the landlords in continuance with their concern for satisfaction and pride and homogenity with 
the residence and the neighborhood.

The concern for homogenity with the community is especially evident in the selection of tenants for the unit. The landlord and the renter seek out the other with similar backgrounds--parties who they feel are friendly and compatible. The compatibility which the landlord considers extends to a potential social concord with the neighborhood. Tenant length of residence tends to be longer in these circumstances. The tenants consider the personal bond shared with the landlord and the community as an additional cost in the decision to move.

Home improvements are determined by the desire to upgrade the property. The rehabilitation work itself is done by the landlord and the tenant. It is subsidized through "sweat equity." Materials needed for improvements are bought with monies from the household budget or other personal funds. Very seldom are funds borrowed. If it is necessary to borrow, friends and relatives are those approached. These loans are then repaid as soon as possible to insure ownership of the property.

Sale of the property is generally a time of life consideration. As has been mentioned, each stage in the life cycle has its particular needs. Sales are made to meet such needs as the cost of college for children or income for retirement. When the sale of property is considered, a purchaser's compatibility with the neighborhood is also assessed. As a result of these considerations in the sale 
of property, a neighborhood stability is reinforced. Longer tenure periods and this selective sales behavior enhance and continue the existing characteristics of the neighborhood.

The process of decline in these communities is usually precipitated by a breakdown in the reciprocity between landlord and tenant. This may happen in several circumstances, for instance, when attempts by the landlord to find tenants or buyers who are desirable are met with failure. There may not be enough households potentially compatible with the neighborhood. This forces the landlord to rent or to sell to those who are less desirable. On the other hand, landlords who operate in this personal manner may leave to be replaced by those whose actions are governed by a more economic rationale. There also may be strong external forces such as cheap external capital available or regulations imposed which force the landlords to alter their behavior and require the landlords to enter into the orthodox econowic milieu. With these changes, the personal friendliness is replaced by more impersonal relations. As the reciprocity in relations dwindle, one notices that the resident landlords become replaced with absentee landlords. Rent levels also increase as dual market landlords, with exposure to the economic market, realize the responsibility for maintenance and repairs and the opportunity costs of their labor. The landlords' considerations change to purely economic returns.

Tenants no longer have the emotional bonds or commitments to the property or the neighborhood. Renter turnover 
is more rapid with their desire for better housing or through evictions due to the lack of consideration for the property. With all of these changes, an instability in relationships and understanding replaces the once stable dual reciprocity in the neighborhood.

\section{RADICAI THEORY}

Underlying the behavior in the neighborhood according to this theory are the power relationships winich exploit those who have neither economic nor political power. The relationship between the landlords and tenants is characterized by conflict spurred by class--the property owners versus the property-less tenants. Wealthy absentee owners who have large holdings seek to preserve the power they have over tine tenants. The landlords organize to set the rents in a monopoly action. This enables them to exploit the property for their benefit. They wish to keep their monopoly positions and reap windfall profits.

Tenant choices are made by landlords in efforts to impede potential tenant organization. Tenants are chosen from varying demographic backgrounds to allow landlords to exploit the social fears and pre-conceived stereotypes regarding various groups. Consequently, the tenants are kept segmented.

In these neighborhoods, there is little motivation or need to refurbisin the structures. Property owners capitalize on existing competition for housing among the low-income 
population. In efforts to continue this trend, maintenance and repairs on the housing is minimal. Housing is kept in short supply and rents are driven higher while costs are lowered. Property owners are able to utilize renovations to maximize their profits. Rehabilition allows for higher rents in efforts to displace old tenants as higher income tenants are sought for tine property.

Capital is the key to housing market dynamics in the neighborhood. The landlords and the financial institutions, who have control of the capital, cooperate in their attempts to exploit the low-income market. Rules in the economic marketplace are created by the distribution of political power. Real political power is in the possession of those with the economic means to instruct others to act for them. The primary force in a decline of a neighborhood is a drive by the owners to "maximize their share of productive surplus" 21 by maintaining a status quo in the power relationships. Une example of techniques used to achieve this is a spreading of rumors in white neighborhoods of minority buying. Such "blockbusting" efforts take advantage of social fears to create massive selling. Banks and other financial institutions cooperate in these efforts by utilizing red-lining techniques. Owners sell for low prices to middle men who in turn sell to minority buyers for high prices.

City government affects the decline of a neighborhood

${ }^{21}$ Solomon and vandell, "Alternative Perspectives," p. 87. 
through the various policies it undertakes. Higher property taxes, strict code enforcement, lower service levels, and rezoning to allow for mixed and undesirable uses are detrimental to an owner-occupant and other small owners. These policies can enhance the cause of the wealthy owners by putting economic constraints on these small owners. These constraints eventually force the small owner to sell. In these scenarios, land use succession is not determined by market forces but largely by political action.

\section{REVITALIZATION}

Revitalization is the recovery of a deteriorated neighborhood. Through major rehabilitation, worn-down older homes are refurbished and appreciate in value. A neighborhood which has experienced a filtering down in housing values undergoes a revitalization in the housing market. In the theories of decline, succession is the movement of households of lower socioeconomic status moving into the areas populated by those of higher status. Revitalization or gentrification can be considered as reverse succession or the replacement of households of lower socioeconomic levels with those of higher status. 22

Generally there are two aspects of the change in revitalizing neighborhoods. They are the changes in the

22 Dennis E. Gale, Middle Class Resettlement in Older Urban Neighborhoods," Journal of the American Planning Association, XIV (July, 1979), 293. 
social and demographic characteristics of the residents and the changes in housing market activity. ${ }^{23}$ The initial sign of revitalization is a rise in the socioeconomic status indicators for the neighborhood. For example, there may be an increase in the number of middle to upper-middle income households living in the neighborhood. There may also be an increase in the number of property renovations or owneroccupied units.

The households which are undertaking these properties for renovation are the risk-oblivious singles or the childless couples, perhaps middle-class professionals. 24 For tine most part, they are white, age 25-34 with four or more years of college. They are usually first-home buyers who filter down to the older housing stock with the intention of refurbishing the property. 25 It is most likely that given the economic conditions of the housing market, this is the property they can afford to purchase. These homebuyers look for an investment property with an expectation of a substantial and relatively rapid capital gain. ${ }^{26}$ This is possible since much of the renovation is achieved through sweat-equity.

${ }^{23}$ Frank F. DeGiovanni, "Patterns of Change in Housing Market Activity in Revitalizing Neighborhoods, "Journal of the American Planning Association, XIIX (Winter, T983), 23. 24 Ibid., p. 24.

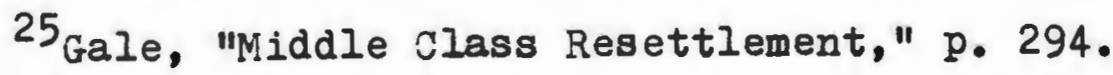
26 Ibid., p. 297. 
Sales prices in the neighborhood do not generally see a drastic increase until the revitalization process is well underway. The neighborhood goes through a slow start, but it soon reaches a point of becoming "trendy." 27 Renovation becomes widespread. The increase in sales prices is due to the sale of the property which was rehabilitated in the first stages of the process. Sales prices are most likely to increase once confidence has been established in the neighborhood, especially when other properties in the neighborhood are upgraded. 28

Speculation with the property is part of this renovation process from its conception. In the earliest stages, the young buyers are not investing in the neighborhood. They have no commitment to the betterment of the community. The property is a means of entering the housing market to start building up equity. Once the changes in the neighborhood become noticeable, speculation increases and is visible through an increase in sales. 29

Displacement is a secondary result of neighborhood renovation and can occur in two ways. The first is as a result of the type of structures undergoing renovation. In the beginning of the process it is the single-family structures which are being refurbished. As the process progresses, a

\footnotetext{
27 DeGiovanni, "Patterns of Change," p. 26. 28 Ibid. ${ }^{29}$ Ibid., p. 27.
} 
number of multiple-family structures are renovated. When these structures are converted to one family units, existing dwelling units are taken out of the market, decreasing the supply of rental units. The renting housenolds are displaced. Additional displacement occurs as the values of the properties increase as they are renovated. The lower-income residents find it difficult to afford the higher rents. As the neighborhood becomes more desirable, rents increase to attract higher-income housenolds. Tenants who cannot afford the higher prices are forced to move out of the neighborhood. Households renting single-family homes are especially susceptible to this displacement. 30 when revitalization is at its peak, so is the level of displacement. Dennis Gale has monitored resettlement in several urban areas and found several implications for the existing theories explaining the increase in the number of households moving back to the cities. 31 According to existing treory, the expensive suburban home prices have forced many to stay in tine cities. However, Gale found that most households remain in the cities for lifestyle concerns, not due to economic reasons. Since most of these households are childless, they do not feel compelled to look for better public education. Moreover, with no children and often with two incomes, these households are better able to afford life

$$
\begin{aligned}
& 30_{\text {Ibid.. }} \text { p. } 27 . \\
& 31_{\text {Gale, "Middle Class Resettlement," p. } 301 .}
\end{aligned}
$$


in the suburbs.

Another theoretical point of difference is the hypothesis that without children the household needs less dwelling and yard space and therefore, it chooses the smaller properties in the urban neighborhoods. Gale argues that in fact the urban homes are more spacious than the new suburban homes. Although the yard space arailable in the city is limited, households with no children are more able to trade yard space for the lower purchasing costs.

Finally, according to present theory, the two worker families have higher commuting costs. A home in the city helps to alleviate these costs, depending on the location of the workplace. While this considers the commuting of two persons, it does not consider the two incomes. These incomes would actually increase the flexibility of the household in their locational choice. In his studies, Gale concluded that it was not as much the economic value in the locational choice as the economic value placed on the architectural, cultural and historical character of an area that was important in the decision to resettle in an urben neighborhood.

LOCALIZED SELF-MANAGEMENT

The development of a localized self-management system within the neighborhood is important to the quality of life in this neighborhood. Crucial to its development is the social contact between the residents. These contacts throughout the neighborhood are interwoven. Together they 
constitute the social network which holds the neighborhood together. This social fabric becomes a network for localized self-management. As such, it is a means of institutionalizing the meaning of being a member of a certain neighborhood. Each neighborhood is different with its own set of norms and rules of accepted behavior. Being a neighbor in one community may mean borrowing and lending while in another it may be keeping to oneself. As a new resident, one has to learn what is an appropriate behavior. This localized selfmanagement is a means of defining the behavior of "neighbor" to newcomers.

The social network as localized self-management is also a means of keeping the public peace. This network has imbedded within it controls and standards which must be abided by as well as enforced by the residents. 32 The residents know the routine of the occurrences in the neighborhood. If any deviations occur, they are recognized as unusual. In this way, the network works as a public surveillance system to protect themselves and strangers in the neighborhood from harm. 33 A trust in one's neighbors is developed.

The growth of such an intricate unconscious network takes time. 34 Cross-links must grow from one cluster of neighbors to the next to encompass the larger neighborhood.

32 Jane Jacobs, The Death and Life of Great American Cities (New York: Random. House, Inc., 1961), p. 31.

33 Ibid., p. 119.

${ }^{34}$ Ibid., pp. 133-34. 
The first step in this is the relationships among the neighbors on one street. It is expanded to develop among those who have something in common beyond the shared geography such as in special interest organizations. Through these, an interwearing network of different relationships becomes a reality. All of this takes time to become aquainted with others in the neighborhood and to develop a means of cooperation. Once this is operating, trust and a confidence in oneself and in the neighbors is in place and a stability has taken root.

Turnover in a neighborhood with such a network can be absorbed. As new residents move in replacing neighbors, they are absorbed into the mainstream and go through an initiation process of learning the norms. However, there is a limit to the degree of turnover which can be absorbed by the network. The increments of change have to be small and gradual to maintain an element of continuity in the process. In a city neighborhood, if the displacement is too rapid, too many of the relationships are disrupted at the same time. This wreaks havoc in a once stable neighborhood. With rapid turnover, the element of continuity is broken; instability is soon to follow. The means of control and maintaining the standards is dismantled. Social problems increase. The mechanism for surveillance and maintaining the peace is dissolved.

This disruption of the self-management network can occur In a neighborhood that is declining or in one which is 
revitalizing. Once the social fabric is disrupted, the stable neighborhood is short-lived. Until a new network can be developed, an element of instability will be present due to the absence of an institutionalization mechanism.

SUMMARY

Each of the theories reviewed in this chapter consider neighborhood dynamics and the impetus of change in a slightly different manner. According to the theories of "Succession and Filtering," the impetus of change is the depreciation in the value of housing structured due to age. This theory contends that the demand of housing is related to the income of a household. Therefore, as the value of a housing structure decreases with age, it is occupied by lower-income households. The "Arbitrage Model of Transition" emphasizes the preferences of a household for housing characteristics which together are called a housing bundle. These characteristics include the neighborhood populations and the physical attributes of the neighborhood as well as the qualities of the structure itself. The household places a value on a dwelling unit in terms of its preferences for its housing bundle. Theretore, the housing dynamics in a neighborhood can be understood through the land uses, neighborhood population, public service and access characteristics as well as the physical quality and characteristics of its housing units. The impetus of change in a nelghborhood market is based on a household's future expectations of changes in its housing bundle and its preference for these perceived 
changes. Households constantly reassess their expectations of changes in their housing bundle in terms of what is happening in their neighborhood and events they believe will affect their neighborhood.

Arthur P. Solomon and Kerry D. Vandell consider neighborhood dynamics based on the motivation and behavior of landlords and tenants. In their "Orthodox Economic Perspective," the motivation is entirely economic. Motivation is for a profit. Therefore, the process of decline begins with lower expectations of returns on the landlords' investment. This can be due to a decrease in demand or to an increase in the costs of supplying the housing. According to their "Dual Theory," the motivation in landlord-tenant relationships is pride in the neighborhood and reciprocity between the parties. A breakdown in this reciprocity begins the process of change in these neighborhoods: either desirable tenants cannot be found or landlords are replaced by those with a more economic rationale. Pinally, their "Radical Theory" contends that underlying the motivation and behavior in the neighborhood are the power relationships which exploit those without economic or political power. A decline is spurred by a drive by owners to maximize their share of the profit. Revitalization is a process of change resulting in the recovery of a deteriorated neighborhood. Worn-down, older homes are refurbished and appreciate in value. Therefore, in neighborhoods experiencing revitalization, the process of change is in the increase in value of housing structures. 
In this type of housing market, speculation and displacement occur as this transition takes place.

The final theory discussed in this chapter is not as concerned with the changes in the physical neighborhood as it is concerned with the social dynamics of the same. Localized self-management is a means of institutionalizing the meaning of being a member and maintaining standards and controls of action in a neighborhood. Since the relationships between the residents necessary for this type of management system take time to derelop, rapid turnover in the population breaks the continuity of the neighborhood relationships. A rapid turnover occuring in either a declining or revitalizing neighborhood can be the impetus of change in the social dynamics of a neighborhood.

As one can see, there are many aspects of neighborhood dynamics to understand and consider for this study. This chapter's review of several theories of urban dynamics aids in an understanding of the process of change in urban neighborhoods. 


\section{CHAPTER II}

THE SOUTH WORCESTER NEIGHBORHOOD

The theories in the previous chapter offer varying viewpoints on neighborhood change. Their ideas are to be considered in this paper in the study of one urban neighborhood. According to the "Arbitrage Model," a household decides where to live based on their needs and preferences in relation to its socioeconomic level. Therefore, the neighborhood's "housing bundle" is an influential element in drawing residents to the neighborhood or sending them to another. For this reason, when seeking to understand the dynamics of a neigbborhood, the existing quality of life should be the origin of the study since it influences who will be attracted to the neighborhood. The character of the neighborhood will satisfy some households' needs and preferences.

The characteristics of the physical structure--its size, modernity, maintenance level--in conjunction with the public services; accessibility to neighborbood land uses, jobs, shopping, recreation facilities; and the socioeconomic characteristics of the neighborhood residents are factors of considerable importance to the identity and image of the neighborhood residents are factors of considerable importance to the identity and image of the neighborhood. Shifts 
in the existing character of the neighborhood may spur an increase of movement in or out. The character of the neighborhood determines who it can best serve. Changes can occur for a variety of reasons. A few families may move for innocuous reasons or, according to the "Orthodox Economic Theory," some positive external influences may draw households out of the area or some negative internal influences may push them out. Therefore, when considering a changing neighborhood several factors must be considered: possible externalities such as new housing, easier access from another neighoorhood; internal factors such as changes in services offered, increase in crime, or disinvestment by the city; or a change in the demographic characteristics of replacement households. Changes in any of these factors can shift the estimated future characteristics of the housing bundle which the neighborhood offers. This may then spur additional morement in or out of the area sending the neighborhood into a spiral of decline or of revitalization. The neighborhood as it has been known will change.

As a point of study in urban neighborhood dynamics, the neighborhood of South Worcester in Worcester, Massachusetts was chosen. This urban neighborhood is considered in detail drawing on the theories discussed in the previous chapter in an effort to determine its neigbborhood dynamics. South Worcester was perceived as being a stable residential neighborhood during the first half of this century. In terms of its housing market, as a dimension of residential 
health, there was a balance between households moving into, staying in, and leaving the neighborhood. 1 In essence, there was a balance between the supply of housing units and the demand for them. As time passed, this neighborhood stability began to falter. Today, city residents consider South Worcester to be a declining urban neighborhood. This chapter begins the consideration of the dynamics which brought South worcester from a stable urban neighborhood to one which is deterlorating. The existing quality of life in the neighborhood is examined to determine the image and identity which Soutn worcester conveys.

\section{HISTORY}

The city of worcester developed a great deal with the industrial revolution. There was an expansive industrial growth in the economy in the city during the nineteenth century. Consequently, there was a burst in the population growth. The South worcester neighborhood experienced the same expansion. Being located a mile and a half southwest of the downtown area (see Figure II-1), it was a logical area for the continuation of downtown growth.

The railroads also had an impact on this neighborhood. Three railroads which enter from the south on their way to the major junction in Worcester travel through South Worcester. Two of them (the Penn Central Railroad and the

${ }^{1}$ Rolf Goetze, Building Neighborhood Confidence (Cambridge, Massachusetts: Ballinger Publishing Company,
$(976)$, p. 30 . 


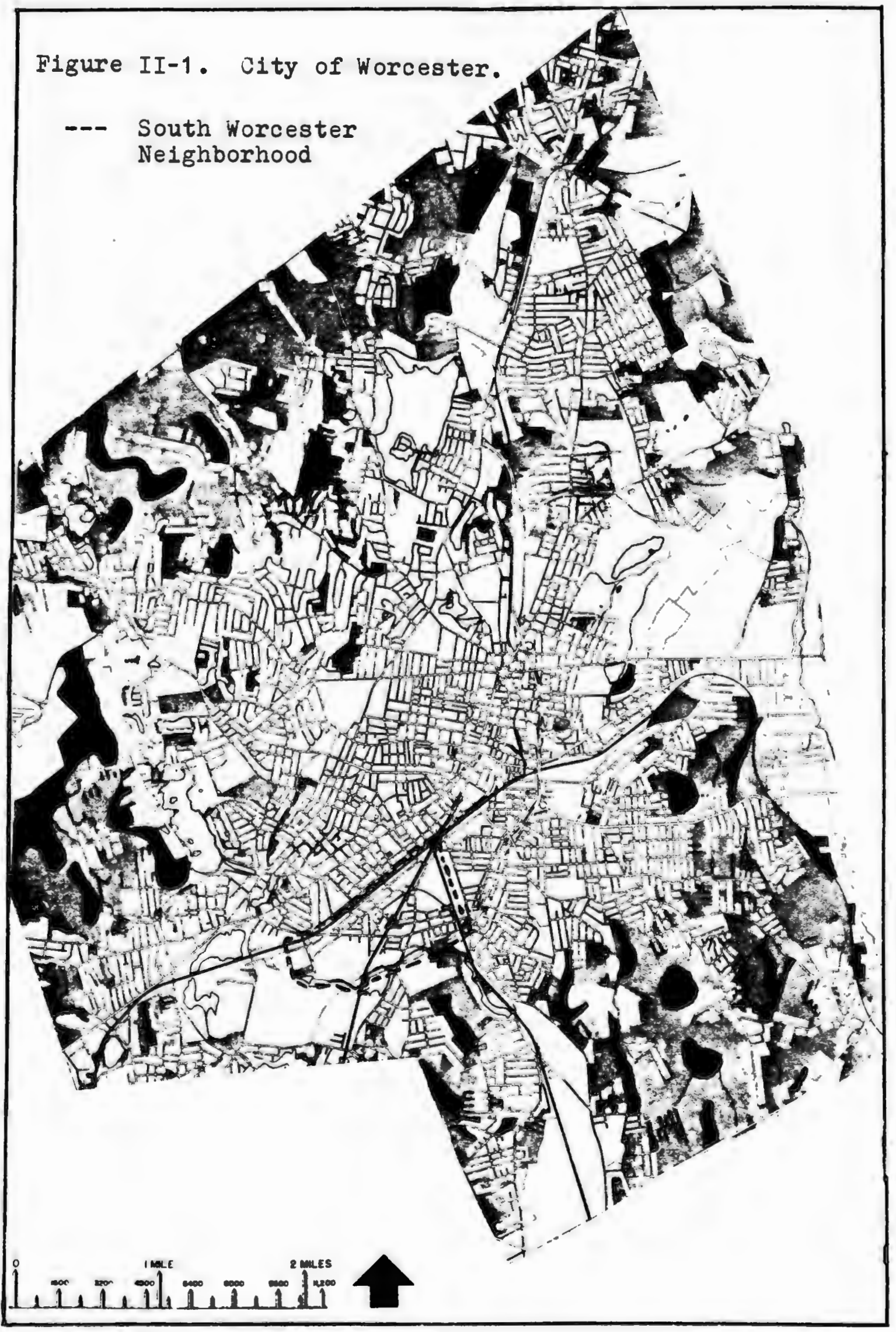


Providence-worcester Railroad) form the north, west and east boundaries of the neighborhood. The third; the New York, New Haven and Hartford Railroad, the Norwich and Worcester Division, divides the neighborhood in half. Industrial growth in Worcester followed the railroads. ${ }^{2}$ It is consistent with this pattern of growth that manufacturing grew in South Worcester.

The growth of industry in South worcester spurred the subsequent population growth in the neighborhood as labor followed industry to south worcester. At the turn of the century, two-thirds of the population were foreign-born, although no one ethnic group was dominant. The ethnic mix was diverse with the Irish and French-Canadian populations (first and second generation) comprising two-thirds of the population. In addition, fifteen per cent of the residents were Yankee and eleven per cent were English. ${ }^{3}$ A majority of the families lived in a building with a family headed by a different ethnic group. This enhanced an ethnic diversity within the neighborhood.

The age distribution can be seen in Figure II-2. The population cohorts decrease close to the ideal. There was no over-whelming imbalance in the age distribution to suggest a burden to the rest of the population. The mean age

${ }^{2}$ office of Planning and Community Development, Existing Land Use, December, 1973 (worcester, MA, 1973), p. 12 .

${ }^{3}$ Community Studies Program, 1900 South Worcester Census Sample, Assumption College, Worcester, MA, 1983. (computer print-out). 
Figure II-2. Age Distribution by Percentage of Population for South Worcester, 1900.

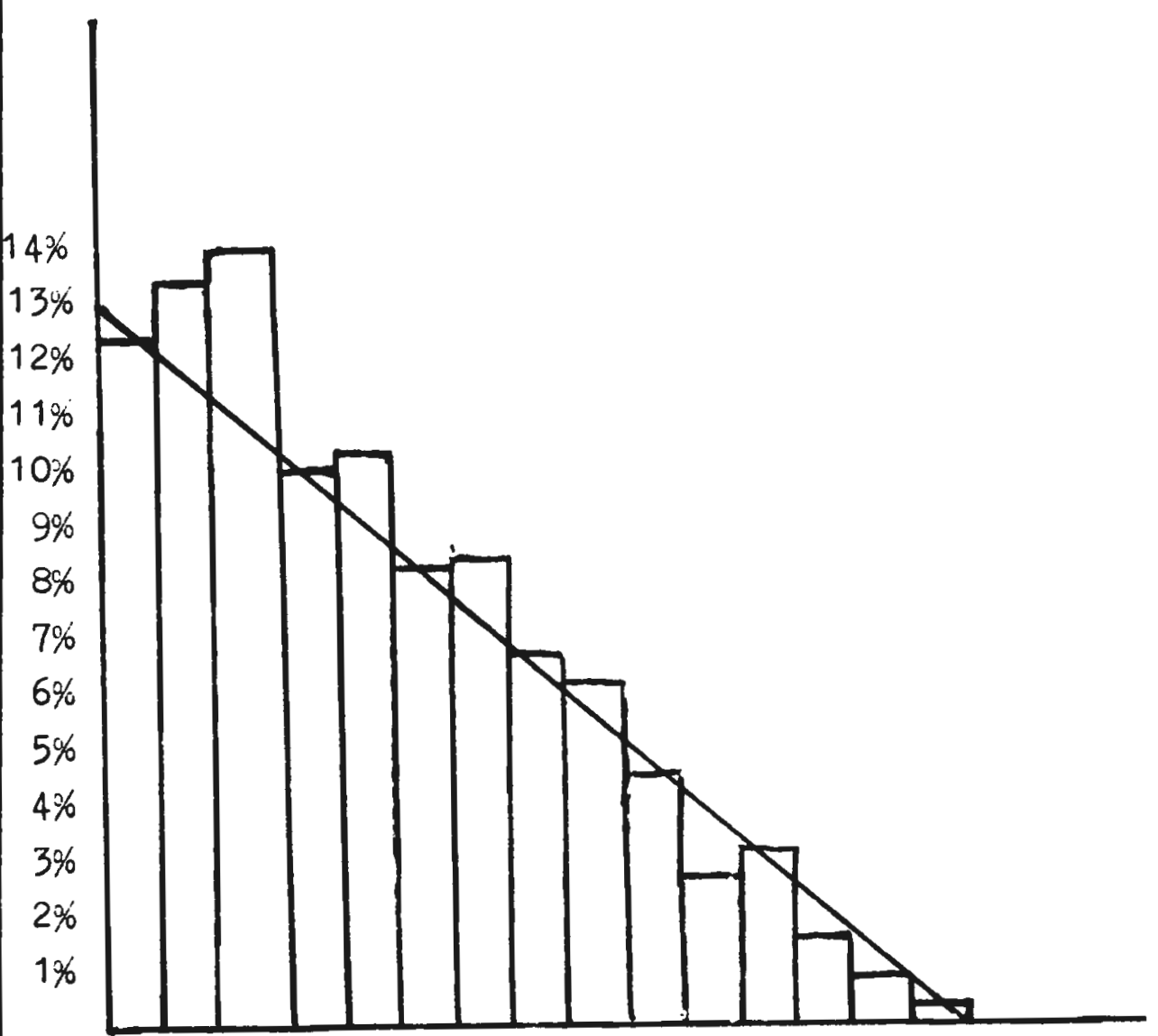

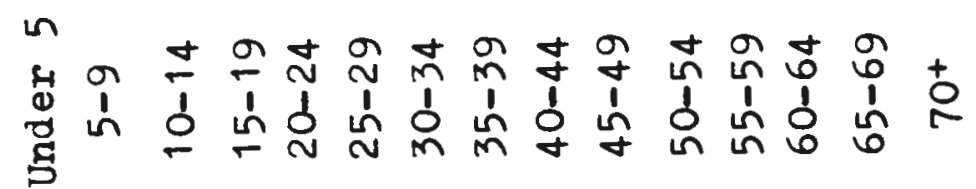

source: Community Studies Program, 1900 Souti Worcester Census Sample, Assumption College, worcester, MA, 1983. 
of the residents was 23.3 with the median falling at twenty. South Worcester has always been a working class towards a lower class neighborhood. These are neighborhoods in which the head of the household is considered to be skilled labor as a service worker (working class) or employed as semiskilled or unskilled labor (lower lower class). ${ }^{4}$ Most of the wage earners in the neighborhood earned their living as either skilled, semi-skilled or unskilled labor. ${ }^{5}$ Nineteen percent of all workers were unemployed at some point for at least one month and fifteen per cent of the head of households for as long as two months. The head of households earned enough to keep their families stocked with life's necessities and sometimes a few luxuries.

Since South Worcester had many different insudtries located there, it is no surprise that the workers were not concentrated in one industry. Machine shops, metal works, textiles, construction and carpet manufacturing claimed most of the heads of households in the neighborhood. 6 There was no dependency on a particular industry for employment. This offered some stability in that the population was not dependent on one manufacturer for employment. The housing in the neighborhood also reflected a

${ }^{4}$ James Arnold Baeker, "Social Class and Family Life Cycle Measures as Indicants of Lower Class Community Perceptions" (Unpublished M.C.P. thesis, University of Rhode Island, 1970), p. 52 .

${ }^{5}$ Community Studies Program, Census Sample. ${ }^{6}$ Ibid. 
working class population. In Worcester there was an extensive industrial growth from 1865 to the 1930's accompanied by an equally expansive population growth. The three-decker housing structure was built in response to the demand for housing for the workforce. ${ }^{7}$ South worcester was a typical nelghborhood in worcester, especially given its location and industrial presence. At the turn of the century the three-decker was not in the majority (fourteen per cent of the structures) although two-thirds of the families lived in multiple family dwellings. 8 In the first three decades of this century, most of the structures built in the neighborhood were the three-decker structures. South Worcester continued to experience a residential stability during this growth period as the supply of housing and the demand for it grew simultaneously.

South Worcester maintained this stability in its residential character until the decades of the 1950's and 1960's. The character of the neighborhood began to change gradually. The three-deckers began to deteriorate; some were abandoned. The population staying in the neighborhood was also changing. The economic status of the neighborhood seemed to proceed from a majority of working-class to a majority of lower-class households.

7 Joel I. Gordon, "The Three-Decker and Its Environment" (Unpublished M.Sc. thesis, Worcester Polytechnic Institute, 1967), p. 17.

${ }^{8}$ Community Studies Program, Census Sample. 


\section{ANALYSIS}

Using the concept of the "housing bundle" (items which households consider when making a locational decision) in the "Arbitrage Model," this section studies the inage of the South Worcester neighborhood as it exists today. There are two parts to this analysis. The first part collects the data which describes the neighborhood characteristics as itemized in Table II-1. Together these characteristics describe the neighborhood of South Worcester and what it has to offer considering it in a locational decision. The second part of this neighborhood analysis is a summary of this information in a quality of life analysis. This study uses the city of worcester as a basis of comparison in determining the quality of life in South Worcester.

Data Analysis

PHYSICAI

The most visible aspect of neighborhood life begins this analysis, namely the neighborhoods' physical characteristics. A neighborhood has boundaries which can be either physical or symbolic and usually both exist. ${ }^{9}$ South worcester is no exception. As has already been mentioned, two railroads form some of its boundaries. An expressway, Route 290, forms a barrier to the south and the Middle River is to the west. This western boundary is reinforced

${ }^{9}$ Suzanne Keller, The Urban Neighborhood (New York: Random House, 1968), p. 89. 
Table II-1. Indicators of Neighborhood Character.

PHYSICAL

-Boundaries

- Iand uses

-Housing units

-physical type

-age

-services

POPULATION CHARACTERISTICS

-Age

-Household composition

-Ethnic groups and race

-Natirity

-Length of residency--permanence

- Iducation

\section{ECONOMIC}

-Occupation

-Employment

-Income

-Rent

-Value of housing

source: Based on the concept of the "housing bundle," "Arbitrage Model of Transition," Leven, et al. Neighborhood Change and Kurt Finsterbusch and H. C. Greisman, "Identifying the Quality Neighborhood," Journal of Urban Analysis, VII (February, 1983). 
by the existence of a relatively large cemetery, saint John's Cemetery, and a smaller cemetery, the B'nai B'rith Cemetery. These serve as a buffer between the residential areas and the river boundary.

Iand uses within these boundaries are diversified with uses in every major category. In 1963, South worcester had the greatest percentage of its land in the city in industrial uses as forty-eight per cent of its area was occupied by industry. 10 This constituted 145 of its 295 acres. The latest land use study for Worcester was completed in $1973 .{ }^{11}$ The neighborhood lost acreage with the construction of the Expressway which took approximately sixty-seven acres. The land use mix has altered to some extent (see Figure II-3). There was an increase in the proportion of residential and commercial uses and a decrease in the industrial use. This would be considered an advantage for the residential neighborhood; however, there was also an increase in the amount of vacant land in the neighborhood. No residential units have been built in South worcester since 1959.12 In the last decade, the neighborhood has witnessed the abandonment of housing and land left vacant.

10 worcester Planning Department, Sketch Plan for Worcester, Massachusetts, May, 1963 (worcester, MA, 1963), pp. 24-27.

11 office of Planning and Community Development, Existing Land Use.

12 U.S. Department of Commerce, U.S. Census, Summary Tract Data, 1980 (Central Massachusetts Regional Planning Commission, 1980), p. 9, Item 12 . 
Figure II-3. Land Use Mixture by Percentage of Use, 1963 and 1973.

1973

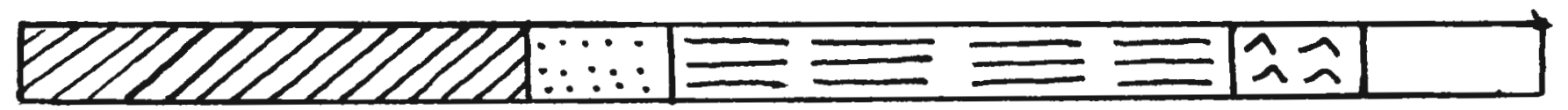

1963

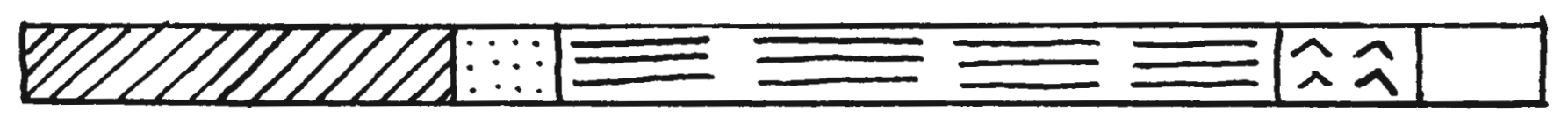

Legend:

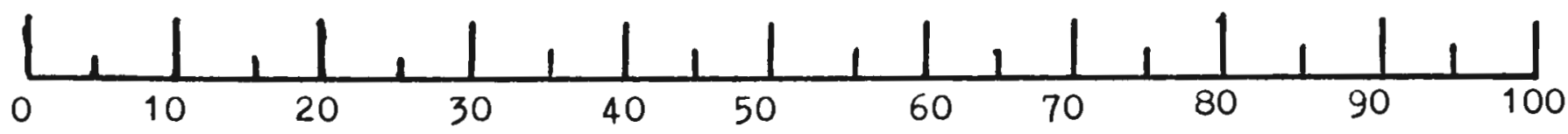

Per Cent

Q7/ Residential

$\because$ Commercial

EIndustrial

A Public \& Institutional

Q Vacant \& Non-Urban 
In South worcester, there are 1314 housing units of which ninety-four per cent (1240) are occupied. The remaining seventy-four units are vacant of which twentyseven (36\%) are for rent and the other forty-seven are considered as "other vacants." This latter class of units can be presumed to be those units standing vacant with no intention of being used in the near future since they are not for sale or being held for occasional use. ${ }^{13}$

When driving or walking through South Worcester, the dominant housing type is the three-decker. Housing of other architectural styles are in the minority in this neighborhood. Only fourteen per cent of the units are single family, detached structures, of the remaining eightysix per cent of the units found in multiple-family dwellings, nearly three-quarters of them are three- and four-family structures. ${ }^{14}$ It is these structures which have the vacant units; all seventy-four vacant units are located in these buildings. 15

The structures in the neighborhood are aging. They are all over twenty-one years old. Nearly ninety per cent of the housing units are in structures built in 1939 or earlier; ${ }^{16}$ the vast majority of the units are over forty-

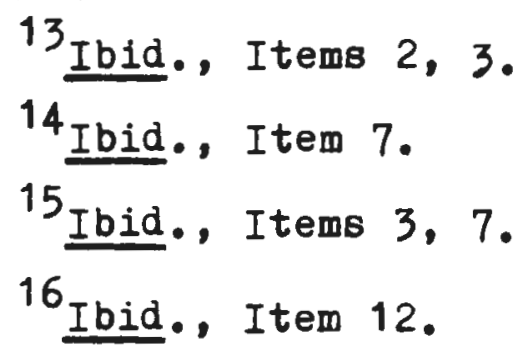


one years old. Since the last three-deckers built in the city were constructed in 1932, 17 it is assumed that these structures in the neighborhood are older than this.

Most of the occupied units use gas as their heating

fuel. It is also the predominant fuel for cooking (17\% use electricity) and for hot water. AIl of the units use water from the public system or a private company and all but six of the 1214 units are hooked into the public sewer system. These six use "other means" of disposal (excluding septic tank or cesspool). ${ }^{18}$

\section{SOCIAL}

There are 3465 residents of South worcester. The age distribution of South Worcester's residents can be seen in the population cohort chart in Figure II-4. There is a significant drop in the population in the age cohorts of 25-34 and 35-44, especially for the male population. In conjunction with this, the jounger cohort of 5-14, the approximate ages of children of the former adult age groups, is smaller than the 15-24 age group. Such an obvious "waist" to the cohort chart suggests that more than natural causes or an expected rate of mobility operates in this population shift. People in this age category are leaving South worcester, making the choice to raise their families elsewhere in the city or in the suburbs.

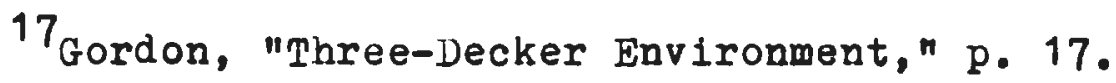
18 U.S. Department of Commerce, Summary Tract Data, p. 10, Item 24 . 
Figure II-4. Population Cohort Chart for South Worcester, 1980.

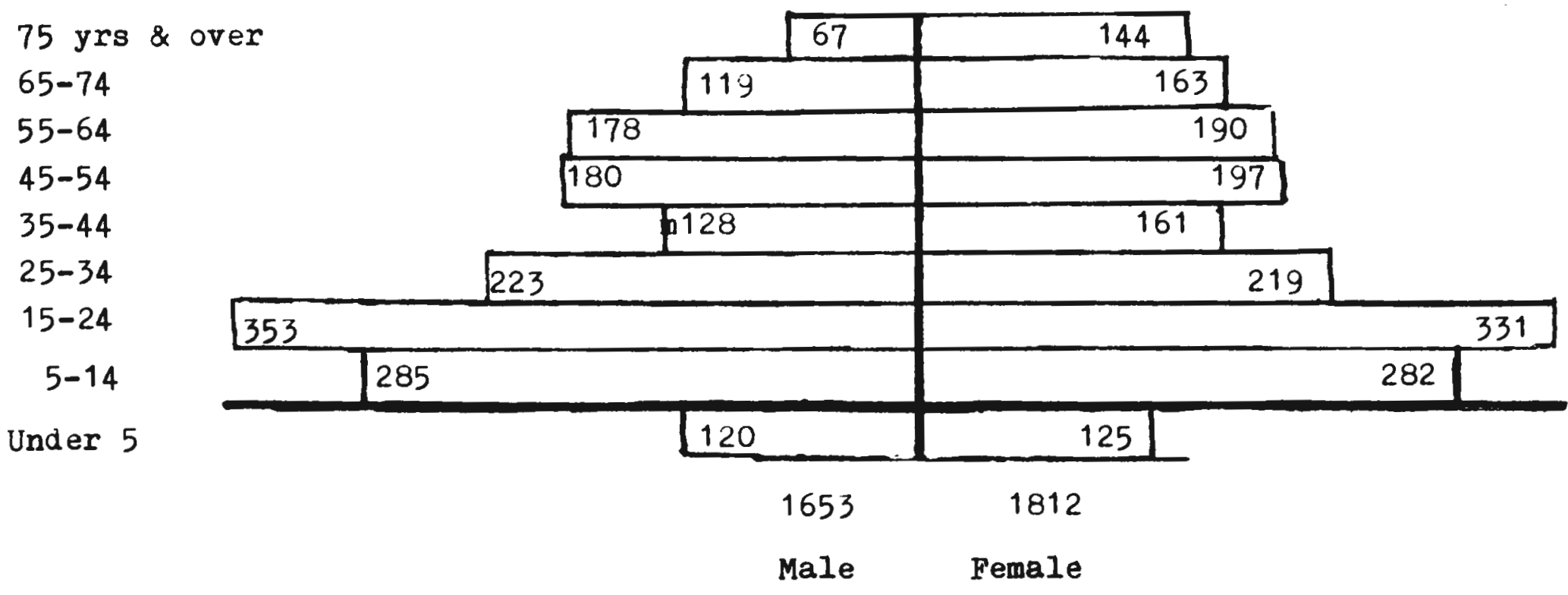

source: U.S. Census, Summary Tract Data, 1980, p. 1, Item 5. 
In terms of the population breakdown (see Table II-2), twenty-nine per cent of the population is under eighteen years of age. School age children $(5-17)$ in South Worcester make up twenty-one per cent of the neighborhood's population. This is a large percentage of the population as compared to the city as a whole. The similar age group in Worcester is nearly four per cent smaller. On the other hand, the percentage of the elderly population, sixty-five years and over, is two per cent lower in South worcester than in the city. These residents form 1251 households (with the exception of sixty-three persons who are living in the two rest homes in the neighborhood). There are 915 families and 336 non-family households. ${ }^{19}$ The average household size is 2.7 members in comparison to the average family size of 3.3 persons. 20

In a closer examination of the 915 families, 330 consist of householders with no spouse present. 21 This is over one third of the family population (36\%). Half of them have children of their own living with them as do the entire number of families.

South Worcester has a large proportion of female headed households. Of the householders with no spouse present, just over three-quarters of them are female headed

\footnotetext{
T9 Ibid., p. 2, Items 10; 11.

20 Ibid.. Table P-1, General Characteristics of Persons, 21 Ibid., p. 2, Item 14.
} 
Table II-2. Demograpinic Characteristics for the Population of South Worcester, 1 y 80 .

Total population:

3465

$\frac{\text { Female }}{1812}$

$\frac{\text { Male }}{1653}$

Age by Cohorts: Under 5

245

125

120

$5-9$
$10-14$

298

$15-19$

269

20-24

327

$25-34$

357

$35-44$

442

$45-54$

289

$55-64$

377

65-74

368

75 yrs + 211

282
211

150

148

161

137

170

166

219

161

197

190

163

144

187

223

128

180

178

119

67

median age: $\quad 29.5$

32.1

$3 \& 4$ years

16 years and over

90

18 years and over

21 years and over

60 years and over

62 years and over

65 years and over

2592

2456

670

597

493

Per Cent of

Total Population

2.60

74.80

70.88

65.22

19.34

17.23

14.23

source: U. J. Census, 1980, Summary Tract Data, 1980, Table P-T. General Characteristics of Persons, p. $\mathrm{P}-4$. 
households (77\%). Ninetyetwo per cent of the families with children where there is no spouse present has a female head of household. In a perspective with the other families who have children, one third of the families in South Worcester, with children, are headed by a woman with no spouse present. Just under half of the population of persons fifteen years and over $(48 \%)$ are married. Of those that are not married, a significantly larger number of single persons are male (16\%) while an equally significant number of number of separated, widowed and divorced persons are female $(16.6 \%)^{22}$ Three-quarters of the female population over fifteen years of age is now or has at some time been married. of these, twenty-nine per cent are separated, widowed, or divorced. This accounts for the large number of female single heads of household.

There is a very small minority population in South Worcester. Less than one per cent each of Black, American Indian, Asian and Pacific Islander, Spanish origin and other racial or ethnic groups $(.89 \%, .38 \%, .66 \%$ and $.38 \%$, respectively) live in the neighborhood. This is a 2.3 per cent minority presence in the neighborhood. This is considerably low in comparison with the city's 7.7 per cent minority population. There is only a small percentage of the neighborhood residents who speak another language (11\%). Most of these also speak English well. Forty-five persons

$$
22 \text { Ibid., p. 1, Item } 7
$$


have limited command of English or do not speak the language at all. Ten of these persons, all eighteen years and over, speak Spanish. 23

There are many nativity groups with which residents identify. They are similar to the ethnic groups of South Worcester's history. French ancestry is identified with by most persons ( $47 \%$ of those who identify with an ancestry group). Persons of Irish ancestry are the next largest group (22\%) and English ancestry is the third group with eleven per cent. Those who identify with multiple ancestry groups select a mixture in which the French, Irish, and English are predominant (in the same rank order). Persons of Polish ancestry are a small proportion of the population (9\%), but they are fairly large in numbers with 153 persons and 109 persons with multiple ancestry groups. 24

Most of the South worcester residents have been living in the central city of Worcester for five years or more. Sixty-two per cent of the residents have lived in the same house for these five years or more. One indicator of a "quality neighborhood" is fifty per cent or more of its population in residence for ten years or more. 25 Fortytwo per cent of South Worcester's householders have lived

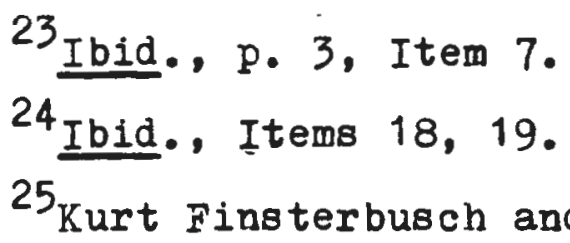
the Quality Neighborhood," Journal of Urban Analysis, VII (February, 1983), p. 123. 
in the same unit for eleven years or more. ${ }^{26}$ In order to determine how many householders have been in residence for ten years, research beyond the scope of this study would have to be undertaken. Fifty-seven per cent of the householders have lived in South Worcester for six years or more. Currently there are 843 persons enrolled in school. Twelve per cent of these are enrolled in private schools, most being in college. 27 of the population over eighteen, thirty-two per cent have graduated from high school. Six per cent have graduated frow college and a few have gone beyond college.

\section{ECONOMIC}

There are 2588 persons in South worcester who are sixteen years of age or older, fifty-nine per cent of which are in the labor force. Table II-3 shows the distribution of occupations of those who are working. Most work in service, skilled, and semi-skilled manufacturing positions (57\%). These could be considered blue collar occupations. There is a higher concentration of these workers in the neighborhood than in the city as a whole. Using Polk categories and figures for 1979 in Table II-4, thirty-four per cent of South Worcester's working population is in blue collar positions. This is ten per centmore than the percentage of the city's blue collar workers.

\footnotetext{
${ }^{26}$ U.S. Department of Commerce, Summary Tract Data, p. 10, Item 13.

27 Ibid., p. 6 , Item 45.
} 
Table II-3. Fmployed Persons 16 years and over by occupation in Status Category, 1980.

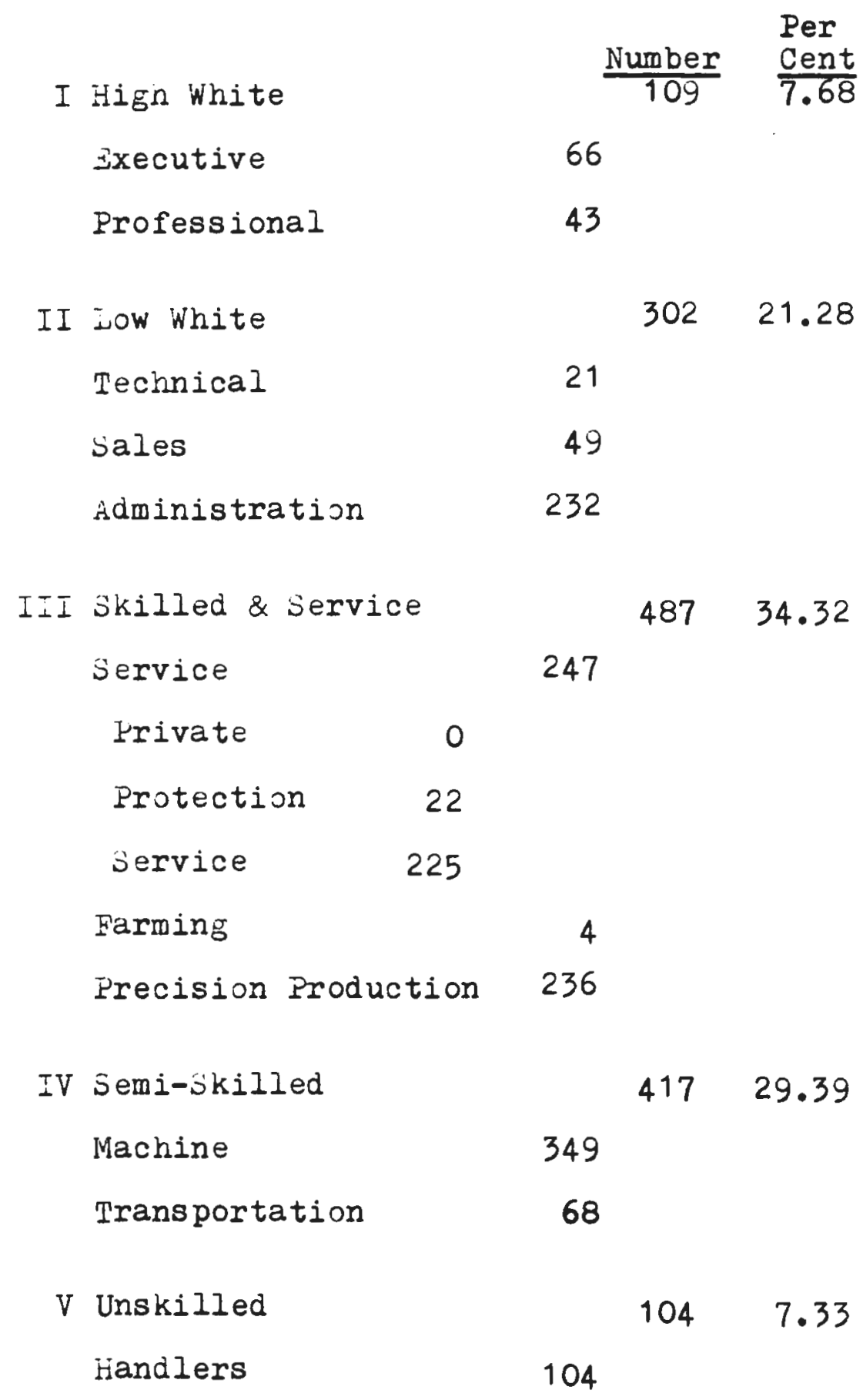

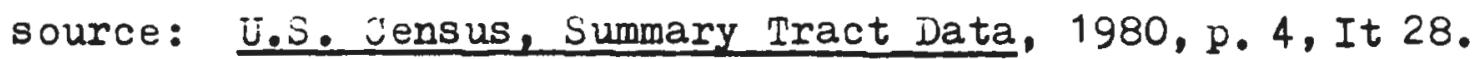


Table II-4. Household Distribution By Occupation for worcester City and South Worcester, 1979.

\begin{tabular}{|c|c|c|}
\hline & $\begin{array}{l}\text { City } \\
\text { Wide } \\
\end{array}$ & $\begin{array}{l}\text { South } \\
\text { Worc. }\end{array}$ \\
\hline Total Housenolds & 57857 & 1244 \\
\hline $\begin{array}{l}\text { Professional and } \\
\text { Technical } \\
\text { \% of Total Heads } \\
\text { of i. H. }\end{array}$ & $\begin{array}{l}4818 \\
8.33\end{array}$ & $\begin{array}{c}27 \\
2.17\end{array}$ \\
\hline $\begin{array}{l}\text { Mianagers \& Propri- } \\
\text { etors } \\
\text { \% of Total Heads } \\
\text { of H.H. }\end{array}$ & $\begin{array}{l}4993 \\
8.63\end{array}$ & $\begin{array}{c}43 \\
7.73\end{array}$ \\
\hline $\begin{array}{l}\text { Clerical \& Saies } \\
\% \text { of Total Heads } \\
\text { of H. H. }\end{array}$ & $\begin{array}{l}4595 \\
7.95\end{array}$ & $\begin{array}{c}74 \\
8.95\end{array}$ \\
\hline $\begin{array}{l}\text { Blue Collar Workers } \\
\% \text { of Total Heads } \\
\text { of } \mathrm{H} \text {. H. }\end{array}$ & $\begin{array}{l}14082 \\
24 \cdot 34\end{array}$ & $\begin{array}{c}423 \\
34.00\end{array}$ \\
\hline $\begin{array}{l}\text { Service workers } \\
\% \text { of Total H. H. }\end{array}$ & $\begin{array}{l}2901 \\
5.01\end{array}$ & 6.11 \\
\hline $\begin{array}{l}\text { tiner Employed } \\
\% \text { of Total H. H. }\end{array}$ & $\begin{array}{l}3192 \\
5.52\end{array}$ & $\begin{array}{c}66 \\
5.31\end{array}$ \\
\hline $\begin{array}{l}\text { No Jccupation Ind. } \\
\text { \& Students } \\
\% \text { of Total Heads } \\
\text { of } \mathrm{H} \text {. H. }\end{array}$ & $\begin{array}{l}7391 \\
12.71\end{array}$ & $\begin{array}{c}179 \\
21.39\end{array}$ \\
\hline $\begin{array}{l}\text { Retired } \\
\text { \% of Total Heads } \\
\text { of H.H. }\end{array}$ & $\begin{array}{l}15885 \\
27.46\end{array}$ & $\begin{array}{c}356 \\
28.62\end{array}$ \\
\hline
\end{tabular}

source: Polk Survey 1977-1979, Jffice of Planning and Community Development, Worcester, MA. 
The unemployed persons in the neighborhood are six per cent of the labor force. While this is lower than the national average, it is slightly higher than the city's average of 5.6 per cent. In 1979, there were 1679 persons in the labor force. Twenty-two per cent of them at some point during the year were recipients of unemployment compensation. The mean number of weeks spent unemployed differs according to sex. Twenty-six persons did not work at all, all were male. Therefore, the average number of weeks of unemployment for males is 15.4 and females, 14.7.28

Over half of the families in the neighborhood have two or more persons working. These families have a mean family income of $\$ 19,254$. This is far above the average household income of 13,785 . Those who are property-owners in the nelghborhood have a higher household income $(\$ 17,298)$ than those who rent $(\$ 12,834) .29$ There are also 160 of the households whose income is below porerty level. 30

Table II-5 reflects these incomes in conjunction with the proportion of income which is spent on the gross rent. The lower the household income, the higher the percentage of the income used for this housing. The average gross rent for the rental housing units is $\$ 195.00$ and the average contract rent is $\$ 118.00$ for the units occupied and $\$ 107.00$ ' for those which are vacant for rent.

$$
\begin{aligned}
& 28 \text { Ibid., p. } 5 \text {, Item } 40 . \\
& 29_{\text {Ibid. }} \text { Item } 40 . \\
& 30_{\text {Ibid., p. } 8, \text { Item } 59 .}
\end{aligned}
$$


Table II-5. Specified Renter-Occupied Housing Units by Household Income in 1979 by Gross Rent.

$\begin{array}{ccccc}\text { Less Than } & \$ 5000 \text { to } & \$ 10000 \text { to } & \$ 15000 \text { to } & \$ 20000 \\ \$ 5000 & \$ 9999 & \$ 14999 & \$ 19999 & \text { or more }\end{array}$

$\begin{array}{lrrrrr}\text { Less Than } 20 \text { Per Cent } & 0 & 13 & 120 & 97 & 166 \\ 20 \text { to } 24 \text { Per Cent } & 0 & 49 & 56 & 14 & 0 \\ 25 \text { to } 34 \text { Per Cent } & 6 & 63 & 44 & 0 & 0 \\ 35 \text { Per Cent or More } & 161 & 65 & 0 & 7 & 0 \\ \text { Not computed } & 10 & 0 & 5 & 0\end{array}$

source: U.S. Census, Summary Tract Data, 1980, p. 11, Item 30 
The mean value of owner-occupied housing units is $\$ 15,776$. This is much lower than the city average of $\$ 39,000.31$ Monthly owner costs for these occupied units decrease with the length of time the mortgage has been held with the lowest monthly costs on those units which have no mortgage. The monthly costs for those households with a mortgage which started between March, 1980 and 1975 are $\$ 342$ per month. This value decreases to \$204 for those with a mortgage from 1959 or earlier. Those with no mortgage have monthly costs averaging $\$ 150.32$

This completes the data base section which has been compiled for the South worcester neighborhood. The information collected covers the various aspects of life described in the "housing bundle" of the Arbitrage Model. Now it must be studied for the quality of life which would be considered by a household in a locational decision.

\section{Quality of Iife Analysis}

Using the information compiled above, the quality of life which exists in South Worcester is examined here. The physical environment, its accessibility and the socioeconomic characteristics of the population are summarized to describe the neighborhood characteristics which South worcester offers households considering it in a locational decision.

\footnotetext{
${ }^{31}$ I.bid., p. 12, Item 34 .

32 Ibid. . Item 33.
} 
PHYSICAI ENVIRONMENT

Major characteristics of the housing and land uses of the area are considered in a locational decision. The large manufacturing land use presence in the neighborhood is a negative environmental consideration. As such, it can also be a factor in the low median housing value. Residences near land uses which have low environmental appeal such as industry, suffer discounts in their desirability and consequently their property value. The majority of the housing units are in multiple-family structures. Most of them are also aging. Ninety per cent of the units were built before 1939. There has been no new residential construction since 1959. The modernity of the units is therefore questionable. With a mean number of rooms at 5.3, they are a good size housing unit for families.

All housing units are connected to either a public or a private company water supply. They are also hooked into the public sewer system (only six units are not). Utility gas hook-ups are also arailable and over eighty per cent of the units use the service for heat, hot water, and cooking.

\section{ACCESS}

Shopping is easily accessible from South worcester. There is a supermarket in the neighborhood at the intersection of the neighborhood's two major arterials--Cambridge Street and Southbridge Street. Smaller markets are located throughout the neighborhood. Shopping downtown at the Worcester Center mall is approximately a mile and a half 
away via Southbridge Street.

The Worcester Regional Transit Authority provides public transportation within the city and to neighboring towns. There are three bus routes which oervice South Worcester; Routes 25, 10 and 31S. Both of the latter follow the same route until they leave South worcester. Route 25 enters from the Worcester Center via Southbridge Street to Hammond Street to Canterbury Street. This services the western half of the neighborhood while Routes 10 and $31 \mathrm{~s}$ travel southbridge street servicing the eastern section. In addition to providing access from the neighborhood to downtown and other points in the city, Route $31 \mathrm{~S}$ provides direct access (no transfers) to the Auburn Mall in Auburn, Massachusets and the Auburn Center.

Access to job markets is fairly east. In addition to the industry in the neighborhood, downtown is a mile and a half away. Access to major transportation routes to Providence, Boston and Springfield open these markets as well. Route 146 to points south is as close via McKeon Road to Millbury Street to the highway as is downtown. Access to Route 290 is possible off of Southbridge Street at College Square just outride of the neighborhood. With such direct routes to downtown and to major highways for points north, south, east and west; South worcester is a prime location in terms of accessibility.

SOCIOECONOMIC CHARACTERISTICS

The quality of a neighborhood has been linked to low- 
turnover and low vacancy rates. 33 Households who stay in the neighborhood are satisfied that their preferences are being met. As long as they are confident that this will continue to be so, they will stay. Finsterbusch and Greisman in their study of "quality neighborhoods" found that these neighborhoods demonstrated stability in other areas as well. They are in family orientation, income and wealth, and status. 34 Consideration of the information on the South Worcester nelghborhood in this light and in comparison with the city as a whole gives an indication of its stability as a neighborhood and as a summary of its neighborhood population characteristics. These are part of the housing bundle it offers in the housing market for households considering it as a future residence.

\section{Family Orientation}

Family stability is considered in terms of the degree that the families are intact. South Worcester is slightly above average in its family stability. There is a slightly higher percentage of households in which there is a husband and wife with their own children. A lower divorce rate and a greater percentage of households of four or more persons accentuate this. The presence of a higher percentage of young also strengthens the family presence; there are five and a half per cent more children under eighteen. A

33 Finsterbusch and Greisman, "Quality Neigbborhood," p. 126 .

$$
{ }^{34} \text { Ibid., pp. 128-29. }
$$


detractor from family stability is a higher percentage of households with children headed by women (four per cent higher than the city). In South Worcester, the average number of children in such families is 1.7. Even with the high number of female headed households, there is a lower percentage of women in the labor force by nearly three per cent. Since non-working mothers are considered to add to family stability, this is a positive factor for family stability.

The mean number of persons per household is consistent with the city at 2.7 and 2.6 (city). South worcester has a lower percentage of one-person households by 2.6 per cent. This factor and the higher percentage of households with four or more persons explains an average family size of 3.3 in South Worcester.

As can be seen in Table II-6, there are no large differences between the city averages and those in the neighborhood. Yet, with the exception of the female headed households, South Worcester does have an overall slightly higher degree of family stability.

\section{Income and Wealth}

When considering income and wealth, the neighborhood is below average. The median family income is $\$ 4600$ less than the city's and 10.8 per cent of the families have incomes below poverty level. This is only three-tenths of a per cent higher than the city's average. The median house value and the median contract rent per month are both 
Table II-6. Indicators of Neighborhood Stability for south Worcester, 1980.

3o. Wor. City

FAMILY ORIENTATION

One-person households

Households of four or more persons

Percent of young

Percent of women in labor force

Percent of married couple with child.

Percent of female householder with children, no spouse present

Mean number persons per household

Percent divorced

23.9

27.4

25.8

46.0

23.3

12.2

2.7

5.5

28.5

24.3

22.9

48.7

22.1

8.3

2.6

6.0

INCOME AND WEALTH

Median income

Home ownership

Percent households with no cars

Percent households with two or more cars

Median house value

Median rent, contract

Percent of households with 1.01 or more persons per room

Percent of families in poverty

$\$ 13,523$

29.4

27.8

17.6

$\$ 17,000$

$\$ 118$

3.2

10.8

2.8

3.7

7.7

Percent minority population

Percent of persons foreign born

Percent of persons 18 years or more

with 12 years or more of school

Percent of labor force unemployed

Length of Residency:

Percent of householders in unit for

11 years or more

6 years or more

42.0

69.0

40.0

54.0

Vacancy Rates

5.6

4.7

source: Finsterbusch and Greisman, "kuality Neighborhood," pp. 127, 128. 
significantly lower than the city's averages by $\$ 12,000$ and $\$ 48$, respectively. South Worcester households also have slightly more crowding in their housing. Almost two per cent more of households are living with more than one person per room in their housing units. The additional indicator of number of cars per household unit also demonstrates a low degree of wealth. There is a higher percentage of units with no cars and a lower percentage of these with more than one car than at the city level.

The home ownership as computed by the percentage of owner-occupied units in South worcester is far below the city's ownership rate. There is such a high number of multiple family dwellings in the neighborhood, especially the three- and four-family structures, that it is virtually impossible for the neighborhood to have a high level of home ownership.

\section{Status}

In four factors considered for status, South Worcester varies. The rate of unemployment, which can also be considered as an indicator of income, is slightly higher in South Worcester than the city (by seven-tenths of a per cent). The lower level of income is a reflection of the degree of blue collar employment in skilled, semi-skilled and unskilled positions. While the unemployment rate could be considered just about average, the educational level is below the city's average. In the city's population of those eighteen years and over, thirty-four per cent have completed 
high school or more. In the similar South Worcester population, thirty-two per cent have completed twelve years or more of school.

Soutb Worcester is slightly above average in its segregation. There is a very small minority population. There is also a low percentage of foreign born persons, 3.7 per cent of the population. Both of these are close to five per cent lower than the city's average.

Synopsis of the South Worcester Neighborhood

A high quality neighborhood has been shown to have a much higher than average family stability and income and wealth factors with average status consideration. 35 South worcester is slightly above average in most aspects of its family orientation. Its one element of instability is in the higher percentage of female householders with children and no husband present. The neighborhood population is considerably lower in income and wealth factors. With more families of four persons or more, they are less able to afford the housing space. This explains the higher percentage of housing units with more than one person per room. While the indicators of status are mixed, South Worcester has a lower income level and a lower education level. In a final summation, the neighborhood presents itself as a white, low-income working class family neighborhood. 
SUMMARY

The desirability of a housing unit in South worcester depends on a household's preference for its particular housing bundle in terms of their income. Each neighborhood, in turn, serves a function by fulfilling the needs and preferences of a particular population. South Worcester has a high percentage of rental units made possible with its multiple-family structures. Sixty-nine per cent of the units (occupled and vacant for rent) are rental units. The neighborhood in this light serves as a renter neighborhood. This could be the neighborhood rrom which households migrate in order to settle in other areas. Dennis Gale suggests that such neighborhoods do not necessarily decline as residents migrate since new renters fill the vacancies. 36 These households are exercising their life cycle option to buy their first home. Since South Worcester has a low number of single family residences, it could be a stopover neighborhood. Another consideration is a possible change in character as new families move in to replace the migrators. As the characteristics of the households moving in varies, the population in the neighborhood undergoes a change. If the remaining residents do not like the changes they perceive and believe that their future property values may diminish, they may decide to leave. A transition begins as the character of those who are remaining is altered. Some renter neighborhoods which are stepping-stones to

${ }^{36}$ Gale, "Middle Class Resettlement," p. 303. 
a higher level of living, have a low degree of continuity with a relatively rapid turnover rate. South worcester, however, is not a neighborhood in which this is so. This neighborhood has a fairly low turnover rate. Sixty-nine per cent of its households have lived in the same house for six years or more and forty-two per cent have been in residence for eleven years or more. These are greater than the city's percentages of fifty-four per cent and forty per cent. respectively. The difference between the neighborhood and the city is not as great at the eleven years or more level $(2 \%)$ as it is at the six years or more level (15\%).

A vacancy rate which is a little above the city's average questions the desirability of the neighborhood. This and the increase in the spread in the percentages between city and neighborhood persistence from the eleven plus to the six plus years of residence warrants closer inspection of the low turnover rate. Is the population remaining because they are limited in their ability to exercise the option of leaving? From 1977 to 1979, the city experienced a loss of one per cent of its households. In comparison, South Worcester lost five and four-tenths per cent of its households. 37 Given the low education level of the population, the low median income, and the high percentage of households with children headed by women, it seems

37 R. I. Polk and Co. Polk Survey 1977-1979, Summary of Key Indicators by Households, Office of Planning and Community Development, Worcester, MA (computer print-out). 
that there is a population which is "trapped." 38 The low rents in South worcester represented by the low median rent is the level they can afford. A similar housing bundle to serve their preferences is not available for less. Forty per cent of the households who are renting (for whom this was computed) spend over twenty-five per cent of their income for gross rent (see Table II-5).

An additional factor for consideration is those units which are vacant and for rent. The mean contract rent of the units occupied is $\$ 118$ as compared to $\$ 107$ for those which are vacant and for rent. In terms of the housing market, the rent asked may have been lowered to attract a lower-income population. According to the "Orthodox Economic Theory," rents decline in a market with reduced demand in the hopes of increasing demand for the units. Lower rents expand the market thus making the units available to lowerincome households. Reduced demand for housing units in the South Worcester neighborhood could be explained by a decrease in their desirability, according to the "Arbitrage Model." The housing characteristics as defined in this theory do not meet the needs and preferences of households making locational decisions. Neighborhood characteristics influence a unit's desirability and, consequently, property values. The next aspect in this study of neighborbood dynamics examines the decrease in the demand of housing. This is done in

\footnotetext{
38 Finsterbusch and Greisman, "Quality Neighborhood," p. 123.
} 
terms of the negative impact which external influences may have on a neighborhood's desirability. 


\section{CHAPTER III \\ URBAN DYMAMICS IN SOUTH WORCESTER}

This chapter continues the effort to determine the neighborhood dynamics in South Worcester. The previous chapter describes the physical attributes of South Worcester and gives a socio-economic profile of the neighborhood's population. Physically, the neighborhood has a substantial industrial presence and aging housing units, most of which are in multi-family structures. Socially, there is a slightly higher degree of family presence in South worcester than the city as a whole. One instability in this family presence, though, is a relatively large number of female head of household with children. Together with the economic profile; that is, the low incomes, low home values and low rents; South worcester presents itself as a lowerincome, working-class family neighborhood.

South Worcester, with its many multi-family housing structures, serves as a renter neighborhood in the city. While some renter neighborhoods are stepping-stones to other areas, this neighborhood does not seem to serve this purpose. Most stepping-stone neighborhoods have little continuity as households are constantly moving in and out. In South Worcester, there is a high degree of persistence. Nearly sixty per cent of the householders have lived in the same 
unit for six years or more and forty-two per cent for eleven years or more. This demonstrates a high degree of continuity in the neighborhood.

As was mentioned in Chapter Two, a "quality" neighborhood would have low vacancy rates together with a high degree of persistence. These do not exist together in South Worcester. This neighborhood has a vacancy rate higher than the city as a whole. While many households are staying in the neighborhood, there are units staying vacant. The rents of these vacant units are lower than those units which are occupied. As has been noted in the previous chapter, these circumstances indicate a decrease in the demand for housing in the neighborhood.

According to the "Ortbodox Economic Theory," rent levels are set according to the market equilibrium at the intersection of supply and demand. If the rents are too high, demand for the unit decreases. An increase in vacancies is usually a sign of demand softening. Rents are then lowered to counter this and to attract more income. A decrease in demand can be due to either more positive conditions outside of the area pulling households out of the neighborhood, or due to negative internal conditions pushing households to other areas.

The "Arbitrage Model" states that households consider a housing unit in terms of their tastes and preferences within the parameters of their income. A unit's desirability then depends on the preference of households for 1 ts collective 
physical and neighborhood characteristics. A household places a value on a unit in terms of its preferences for these particular characteristics. As a unit becomes less desirable, its value decreases in the eyes of the households, thus its monetary value decreases as well.

Considering the high vacancy rate and the lower rents for the vacant units, it can be inferred that demand for these units has decreased. The rents are lowered to attract new households. It can also then be inferred that the units' desirability to households has decreased. Conversely, households' preferences for these units with their particular housing characteristics has diminished.

what has occurred in South Worcester to alter the neighborhood characteristics so that units in the neighborhood have diminished in desirability and demand for units has decreased? During the 1960's, there were two city actions which effected changes in South worcester. In 1963, a new zoning ordinance was instituted. Then, in 1966 the Expressway, Route 290, was built. This highway is one of the borders to the neighborhood. This chapter considers these events for the effects they have on the south worcester neighborhood in an effort to determine the dynamics of neighborhood change in this neighborhood.

\section{ZONING}

In 1951, Worcester's zoning ordinance had three categories of land use: residential, business and industrial. South worcester had only one small area zoned Residential "C" 
where high density residential uses were permitted. An equal area was set aside for business and the rest was zoned industrial. In Figure III-1, one can see that the limited residential and commercial districts were virtually surrounded by the industrial district.

The 1963 zoning ordinances redefined and expanded the zoning classifications. Instead of a single industrial classification, Light and General Manufacturing were separated with several degrees of "Floor Area Ratios" for density control. 1 The effect in South Worcester was to limit heavy industrial land uses to certain areas. The existing residential area was expanded to include most of the former commercial area. Two additional residential areas were created, one of which is larger than the 1951 district. Commercial areas were created in three major traffic areas within the neighborhood. Light manufacturing zones were put in place as buffer zones between the heavy industry areas and the residential districts (see Figure III-2).

With the rezoning of South Worcester most of the zoning districts coincide with the existing land use. One exception is the eastern corner of South Worcester which remained classified industrial as MG-4.0 and MG-2.0, General Manufacturing of the greatest density. Land use in this area is residential with manufacturing on three sides. Instead of a buffer zone as was used in other areas in the

${ }^{1}$ worcester Planning Department, Sketch Plan, p. 45. 


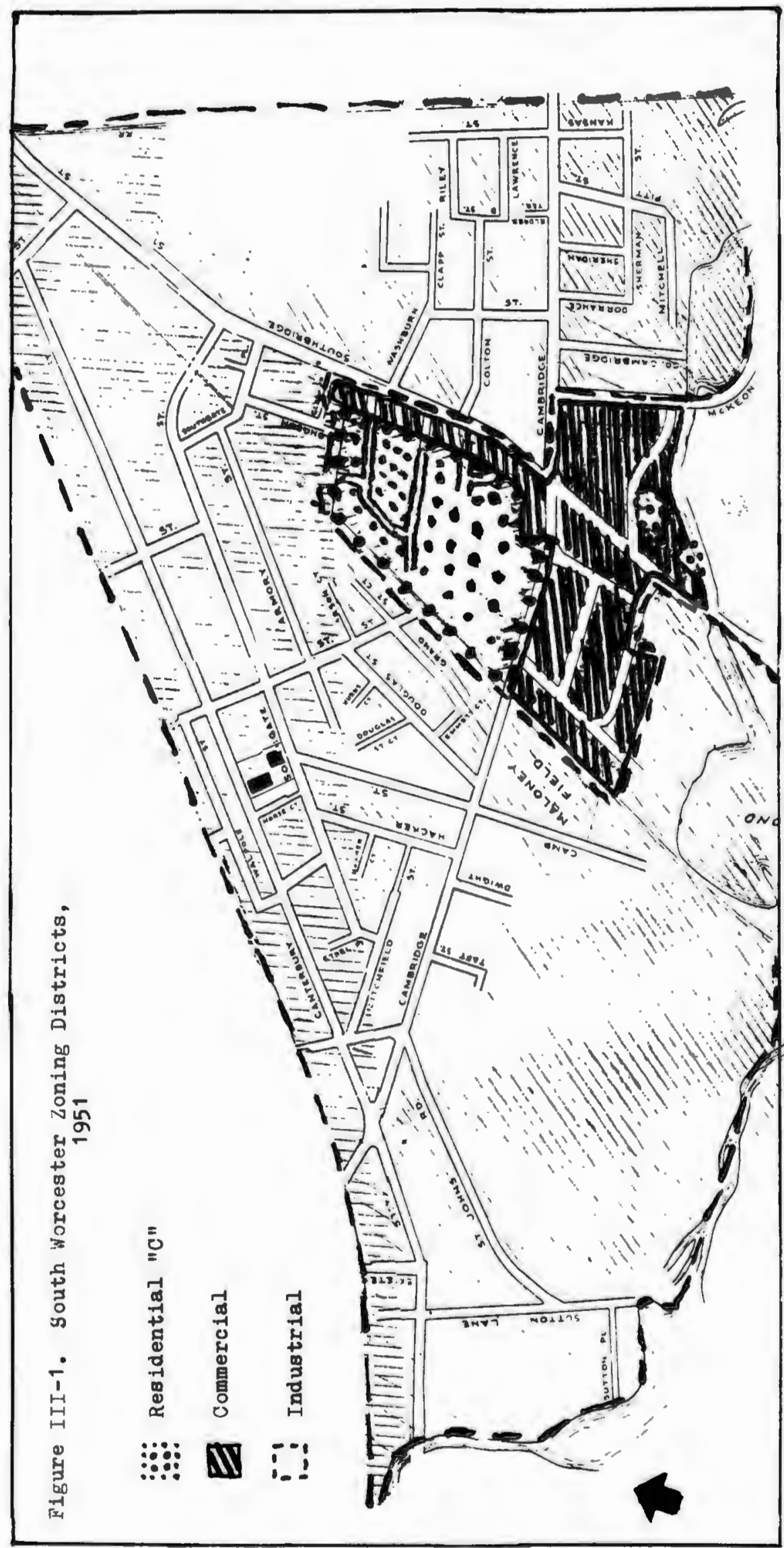




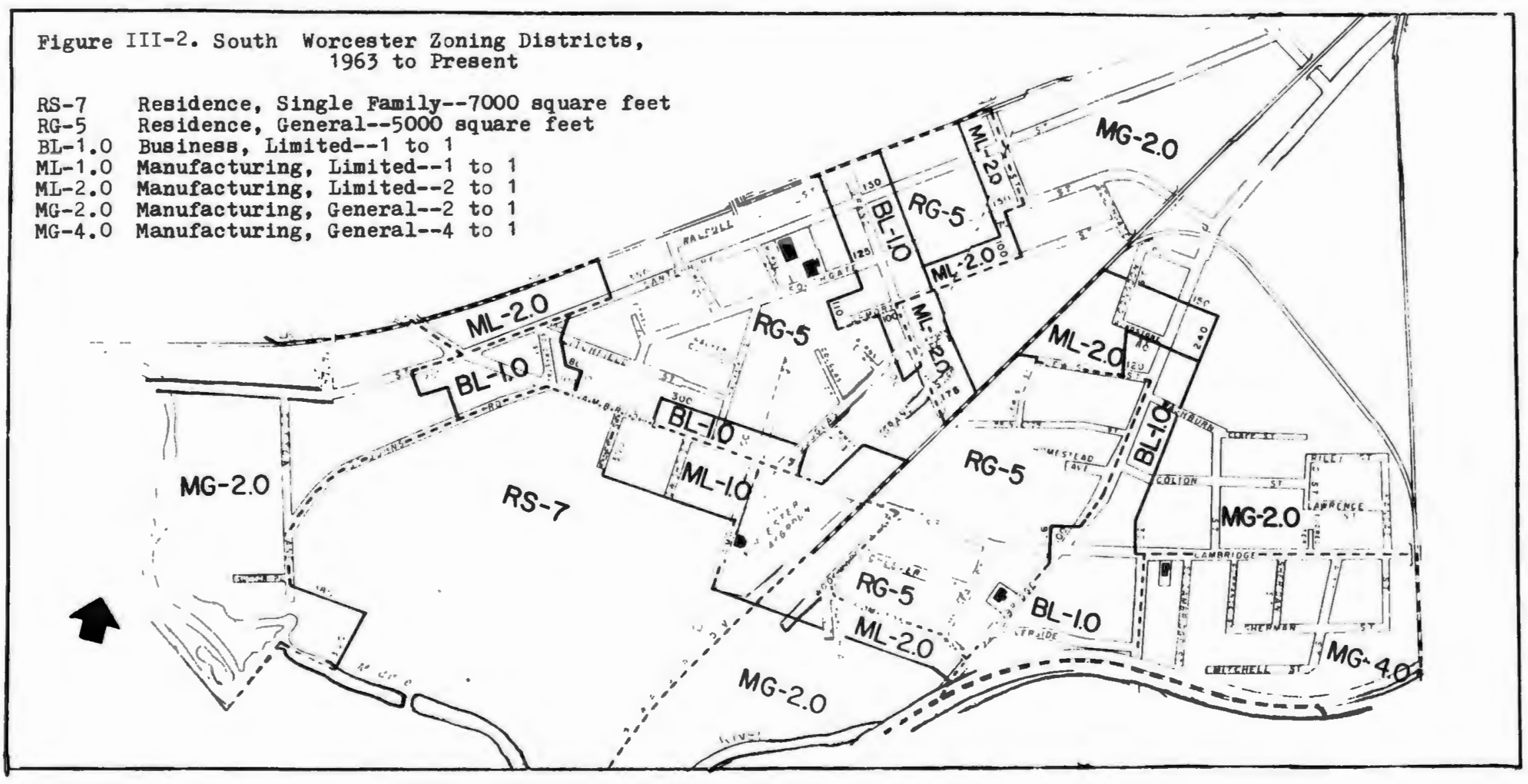


neighborhood, this whole sub-neighborhood remained industrial. It is the only area in South worcester which is inappropriate in its zoning classification. As such, it serves as an area of study for the effect, if any, which the zoning as a government policy has had on the dynamics of the South worcester residential neighborhood. In this study, this industrial area is compared with another subneighborhood which is zoned RG-5, General Residence with a minimum lot area of 5000 square feet. The two contiguous manufacturing districts mentioned above are combined so the areas for comparison are approximately the same size and large enough to determine trends. They are defined as $M G-2.0$ and MG-4.0, General Manufacturing with floor area to land use ratio of 2 to 1 and 4 to 1 , respectively. Figure III-3 is a delineation of the areas of comparison.

If zoning has a negative effect on an area's stability, the MG-2.0 and 4.0 district would be experiencing more negative effects than the RG-5 district. Zoning's initial purpose was to eliminate negative external effects by separating incompatible land uses." "The separation of residential zones...from industrial and commercial activities is justified on the grounds that traffic and visual externalities associated and generated by these non-residential activities will detract from the residential

2 David E. Ervin, et al., Iand Use Control: Evaluating Dconomic and Political effects (Cambridge: Ballinger Publisbing Company, 1977), P. 61. 
i

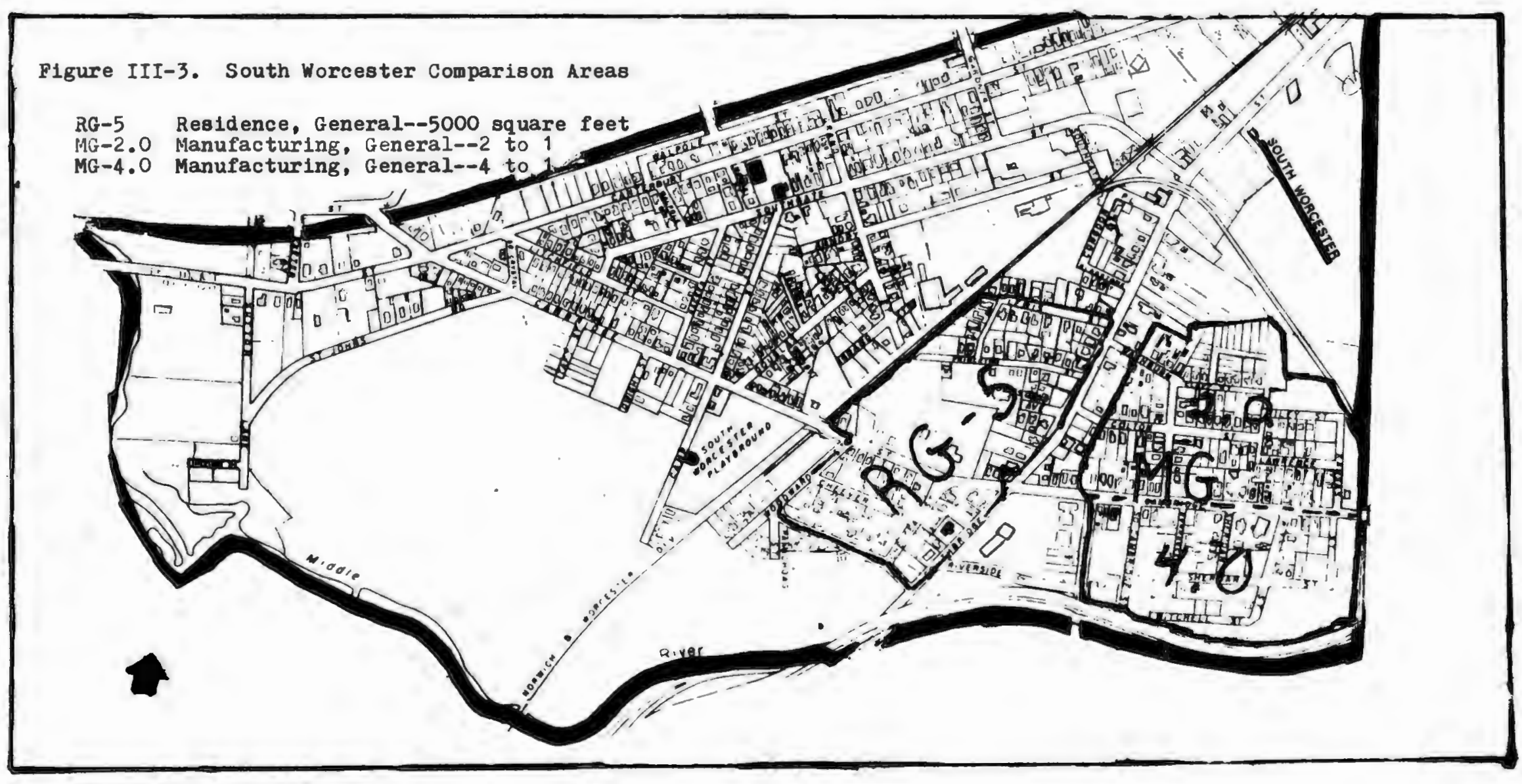


amenities." 3 These negative external effects alter the perceptions of households regarding a piece of property. According to the "Arbitrage Model," once external effects are categorized as negative by households, they are avoided in locational choices to the extent possible. In their perception, the value of the housing bundle is lowered as a discount for being near a negative use. Expectations of lower property values in the future from the negative externalities of non-residential uses cause rasidents to leave if is possible, or to experience a filtering down in their preferences for housing if they remain in the neighborbood. Non-resident owners who perceive risks of losing investment on property by a reduction in returns may not continue with the necessary maintenance. A decline may be initiated or an existing decline may be emphasized. Loning was intended to limit such potentialities. However, zoning can, in effect, also increase the expectations of future external diseconomies if non-residential activities are permitted. A household may perceive a potential decrease in the value of their housing bundle due to expected externalities from such uses. Neighborhood instability can be exaggerated as a result of the estimated effect of the expected future land uses in an area zoned permitting non-residential land uses. According to these theories then, the residential

\footnotetext{
Feter Mieszkowski, "Notes on the Economic Effects of Land-Use Regulation," (paper presented at the XXVIII Session Confreds d'Institut International de Finances Publiques de New York, 1972), p. 270.
} 
neigbborhood in the $M G-2.0$ and 4.0 district would be more negatively impacted by the diseconomies of the negative visual externalities, the excess noise and air pollution and the traffic hazards from the existence of non-residential uses such as manufacturing, than the $R G-5$ district where these uses are not permitted.

To determine if the MG-2.0 and 4.0 district has experienced more negative effects from its zoning classification than the RG district, information regarding tenure, occupance, crowding, ownerstip, unit size, loss of housing, land use and some socio-economic characteristics for each district is usea in the comparison. Data also was collected for each structure in the districts. The base year was 1960. Five year intervals were the aim, however, data sources were notavailable for 1965 or 1980. The years 1966 and 1979 were used as substitues. Information on the building type, land use, the owner, owner's residence (by owner-occupied, South worcester resident, or absentee), and the number of vacancies in the structure was collected for each study year. This data also provides information on which units no longer exist.

Over the study period of 1960 to 1979 , close to nineteen per cent of the RG districts housing units have been torn down. Not included in this figure is the six percent of the units that were taken out of the market for other reasons by their owners. In the same period, the ownership mixture of the units has altered. The percentage 
of units in the buildings with the homeowner present has dropped twenty-two per cent. At the same time, the ownership of units by residents in other areas of South Worcester bas fallen by thirty-seven per cent. As investment on the part of residents has been falling, the presence of the absentee and realty company owners has been rising. The percentage of units in buildings with homeowners in residence has dropped twenty-two per cent while absentee ownership has risen twenty-two per cent and realty company ownership by sixty-six per cent. In addition, two parcels of land are owned by the city, after the loss of the units. They are still vacant lots. The increasing outside ownership is indicative of a loss of confidence in the neighborhood. With over half of the units owned by non-residents, this is an unstable market which suggests a lack of confidence in the district. Housebolds' estimates of their future returns on their property seem to be gloomy.

Tracing the vacancy rates through the study period demonstrates the existence of decreasing expectations by property owners. In 1960, the vacancy rate was just above one per cent. By 1966, it had climbed to 6.4 per cent. Demand for units had decreased; therefore, as the "Orthodox Economic Theory" contends, cash returns were reduced. Expectations of the future returns were lowered. The response by some was to sell. The first few parcels to be sold were redeveloped as commercial land uses. Other owners took units off the market, perhaps as expanded living space 
in existing units.

By 1970, the shift in the market by a reduced supply due to demolition and units no longer in the market had countered the softening demand and reduced the vacancy rate. It was not long in lasting. In the unstable environment, vacancy rates continued to increase and the demolition of structures continued. By 1979, the vacancy rate was almost at nine per cent and the RG district had lost close to nineteen per cent of its housing units and approximately six per cent had been taken out of the market. The RG district had lost twenty-five per cent of its housing market over a nineteen year period.

The MG district has had 23.4 per cent of its housing units torn down over the nineteen year study period. Even with this loss, demand for units is low. There is an eight per cent vacancy rate in 1979. The results of the lost units has actually been beneficial to its ownership mixture. The percentage of owner-occupied units has increased by twentythree per cent. There has also been a nineteen per cent increase in the percentage of units in structures in which homeowners are present. The percentage of one-family dwellings has increased by approximately twenty-three per cent and could partially account for the twenty-three per cent increase in homeownership. However, there has also been a sixteen per cent increase in the owner-occupied structures. The owner-occupancy of units is 28.3 per cent and the owner-occupancy of structures is 60.2 per cent. 
As there has been an increase in the percentage of units in structures where the owner resides, there has also been a decrease in the percentage of units owned by absentee owners. Almost twenty-two per cent of the units in 1979 are owned by absent persons as compared with the 30.4 per cent in 1960. This is a twenty-eight per cent decrease in absentee landlords.

The increase in resident ownership and the decrease in absentee ownership seemingly point to a confidence in the district by residents. Some of the population characteristics also seem to indicate that the MG district is more stable. Nine per cent of the population in the RG district are minority, either Black, Asian and Pacific Islander or of Spanish origin. The minority population is much smaller in the MG district. Only four per cent of the population is of a minority group.

The MG district also has a much higher percentage of young population than does the RG district which suggests more of a Iamily presence. I'here are nine per cent more persons under eighteen in the MG diatrict. The percentage of single heads of household, with children is fairly even. The MG district with 12.8 per cent has approximately one per cent less than the RG district. Both are less than the South Worcester percentage of 18.3. An element which detracts from saying that the MG district is more family oriented is a significant proportion of one-person households. The percentage is close to seven per cent higher 
than that in the RG district. There is slightly more crowding in the RG neighborhood where the percentage of households with 1.01 or more persons per room is almost one per cent higher than in the MG district. The lower density factor in the MG district may be due to the higher percentage of one-person households since the average number of rooms per unit is virtually the same as those in the RG district. The increase in resident ownership and the decrease in the absentee ownership in the MG district seem to point to a confidence in the district by its residents. The RG district is experiencing opposite trends in ownership. Its resident ownership decreased while the absentee ownership increased. These market dynamics and the population characteristics suggest that the zoning of the MG district has not been detrimental to its development. The RG district experienced disinvestment by resident owners demonstrating it to be an unstable housing environment. The MG district has not suffered this resident disinvestment.

Do these factors indicate a more stable housing environment in the MG district? The confidence in the MG district as a housing environment does not seem to be shared by property owners who reside in other areas of South Worcester. In 1960, ownership in the MG district by other South Worcester residents was 19.5 per cent. By 1979, this percentage had fallen forty-nine per cent. Such a high rate of selling by these property owners hints at problems in the market. Further consideration of the housing market in the 
MG district demonstrates that more instabilities are present bere than in the $R G$ district.

The average house value in the MG district is $\$ 16,000$. This is much lower than the mean of $\$ 20,000$ for the RG district and is $\mathrm{six}$ per cent lower than the average $\$ 17,000$ for South Worcester. The mean contract rent is also much lower than the RG district $(\$ 116)$ and South Worcester (\$118). Its mean contract rent is 101 per wonth. These housing values in the MG district combined with the eight per cent vacancy rate suggest a low demand for housing in this area. According to the "Arbitrage Model," the price of a unit is determined by the desirability of its housing bundle. This suggests that the units in the MG district have less desirable housing and environmental characteristics than the RG district. Realty ownership in the MG district has also increased by 178 per cent. Such a large increase in these owners further indicates a decline in the MG district. While the increase in realty owners in the RG district was sixtyfive per cent and also indicates decline in that district, the percentage change in the MG district is wore than double that in the RG district.

In 1979, Worcester city owned four structures in the MG district. They are part of properties which were owned by two multiple property owners and are currently owned by the city. While four structures were still otanding by 1978, others on the properties had already been torn down. These four structures have since been removed. There are 
vacant lots where they once stood. In addition to the units the MG district has lost to demolition, seven per cent of the units have been taken out of the market. Over the study period, the MG district bas lost thirty per cent of its housing supply.

It is evident from the elements of instability in each district that both are experiencing a decline. The housing bundles these districts have to offer perspective households is not as desirable as other choices available so it is difficult to fill the housing supply. Between 1960 and 1979, the housing supplies have been shrinking in response to a softening in the demand for units. In 1979, the vacancy rate for the $R G$ district rose to 8.95 and 8.1 per cent for the MG district. In response to these high vacancy rates, the MG district has lost five per cent more units (30.4\%) than the RG district.

In this process of decline, according to the "Orthodox Economic Theory," homeowners sell in an attempt to get its present value before the return on investment goes lower. Some may move and keep the property for investment and become landlords themselves. This is part of a rise in absentee owners. If they encounter problems with tenant delinquencies or with finding tenants, the property may become more of a burden than an investment. They may try to sell and are unable to get a buyer. Often they sell to real estate companies. The absentee owners and the realty companies are in a better position to take the risks, and 
absorb the costs of low return on their investment in such property while waiting for a future profit.

The MG zoning classification has had some ramifications in the redevelopment of some of the parcels whose structures were torn down. One cluster on the corner of Cambridge Street and Washburn Street has been used for expansion of a wholesale and retail fence business. This is not a permitted use in a residential district. Another cluster of parcels along Kansas Street, both sides from Cambridge, and the corners of Kansas and Lawrence Streets have been bought by Babco Realty, Inc.. Those properties on the southern extension of Kansas Street have been rebuilt for the Bloomfield B. Company (now Babco Metal Company), an industrial scrap metal company. The property on the corner of Cambridge Street and the western side of the northern extension of Kansas Street and the corner of Lawrence Street are still vacant lots. A remaining one-family house is presumably preventing further expansion. As a result there is a very large area of vacant land which has a negative effect on the residential area surrounding it.

The residences in the MG district are experiencing a filtering down process which is indirectly due to the zoning classification. Zoning of residential areas for more intensive uses (that is non-residential uses) may not be harmful to the area at first. However, over the long term it can prove to be detrimental to the residential environment. As the more intense uses spread, the property values of the 
residences decrease due to the diseconomies of being located next to a non-residential use. ${ }^{4}$ In this manner, the zoning classification of MG 2.0 and 4.0 has had ramifications on the residential uses in the district. The expansions of the businesses hastened by the expressway (to be discussed) has had a domino effect on the housing surrounding them. As the businesses expand, their field of negative impact encompasses additional dwellings. This in turn lowers the price of the property.

In the MG district the properties on Dorrance, Sheridan, and Pitt Streets are well maintained. They are bordered on three sides by industry on the other side of which is Route 290. The D Street area, however, is less maintained. This is the location of a cluster of vacant lots which includes the city owned property. A trucking and salvage company is located near here. If this industry were the sole reason for the residential deterioration of this area, why the lack of deterioration in the area virtually surrounded by the industry? One reason could be the benefit that the Dorrance, Sheridan and Pitt Streets receive from being located near a church. More importantly to the D Street area is the poor environment surrounding it. The vacant lots of Babco Metal Company are exerting their influence and may have been an impetus in its decline. Also significant to the D Street area is the proximity of one of the railroads which borders

\footnotetext{
${ }^{4}$ Ervin, Iand Use Control, p. 24.
} 
the neighborhood. Across from dwellings on Riley Street (two structures have been torn down here) is a large amount of vacant land which reaches to the railroad.

These aspects of the filtering process in evidence in the MG district affect the opportunity of the property owners to sell. As is asserted in the "Arbitrage Model," future estimates of property values are based on perceptions. With a visual demonstration of the housing deterioration in progress, the expectation of decreasing housing environment becomes more definite. In this environment, the selling of one's property to another homeowner becomes difficult. In effect, the best opportunity to sell is to an industry or other use not permitted in an RG district. Unless one's property is located near an existing business, this may not be an option.

The resident owners may want to sell, but may not be economically able to move. The low prices that would be received for the sale of the property to another homeowner may not be enough for a better housing environment without additional funds. The high vacancy rate and the low property values demonstrated that the housing bundle is not as desirable as those available elsewhere. Without a buyer for the property at a price necessary for relocation, the resident homeowner is essentially trapped with no option but to stay. 5

\footnotetext{
5 Finsterbusch and Greisman, "Quality Neighborhood," p. 123.
} 
The increase in the percentage of units in buildings occupied by the owner and the decrease in the units owned by absentee parties is a result of the trapped population of resident owners. As the costs of supplying the housing overrun the income it generates, the non-resident owner is able to sell at a low price or tear it down and retain the property for future gains. While units are demolished, the resident owner stays and maintains his property to the best of his ability. As the number of units decrease, the proportion of resident owners to non-resident owners increases even though the absolute number of resident owners does not increase. The percentage of one-family dwellings bas increased by twenty-eight per cent. This is not due to any new building, but to the loss of multi-family dwellings.

The RG district with its bigher mean housing values and higher mean contract rent demonstrates a higher element of wealth. It gives a better perception of future property values and returns. This is important to those investing in the property. It gives the resident owners of this district more opportunity to sell their property and leave if they are not satisfied.

\section{EXPRESSWAY DEVELOPMENT}

The second event considered for its impact on South Worcester is the building of the expressway Route 290. This highway connects with Route 146 south of the neighborhood to bring traffic north through the city of Worcester. Along its route, it borders the neighborhood of South Worcester. 
Construction of a major highway such as this can have negative effects on neighborhoods. In addition to the land it takes, there is an increase in traffic as drivers access the highway. This leads to an increase in the safety hazards to residents of the neighborhood. There is also an increase in the noise and air pollution from traffic accessing and utilizing the highway. These factors have a negative environmental impact on the residential ambience of a neighborhood.

Route 290 seems to have affected the neighborhood of South worcester. Referring to the sub-neighborhoods studied in the zoning section, the expressway is very close to the lower portion of the RG district and it is a border of the MG district. The softening in demand seemed to be exaggerated by 1966 when the vacancies jumped in both districts. This is the same period during which the expressway, Route 290, was built.

The low vacancy rates for both districts in 1960 suggest a balance between demand and supply. Most of the structures removed in the MG district by 1966 were related to the expressway and the first structures gone from the RG district in the study period were between 1966 and 1970. Of the first structures gone in each district (MG: 13 in 1966; RG: 5 in 1970), twelve were in areas most affected by construction of the highway. In the MG district, Mitchell Street and its three structures were eliminated. Other structures were absorbed by industry in the area. One was 
absorbed into the living space (extra yard) of the owner. In 1970, three parcels in the RG district were used for the construction of a Texaco tation on Southbridge Street approximately half a wile frow on and off ramps from Route 290 and the College of Holy Cross. Later a fourth parcel was added for a parking area.

Increased traffic along Cambridge Street and Southbridge Street to and from the highway added to the air pollution, noise and safety hazards. These factors combined for negative environnental changes in the neighborhood and its residential amenities. In this way, the expressway altered the neighborhood characteristics so that units diminisbed in desirability.

SUMMARY

The zoning ordinance of 1963 in conjunction with the construction of Route 290 have worked together to evoke changes in the residential environwent in South Worcester. These city actions and the changes they wrought prosote a shift from residential to the more intensive non-residential land uses. Route 290 led to the loss of units and an increase in negative environnental factors. The zoning classification of MG 2.0 and 4.0 permitted the expansion of non-residential uses sucb as business and industry into lots left vacant by the $108 \mathrm{~s}$ of housing structures. The negative impact from both the expressway and the expanding industry altered the neighborhood's physical environment. Zoning in the MG district increased the expectations of future 
external diseconomies from the permitted non-residential activities. There was a decrease in the quality of the environmental characteristics in the area. According to the "Arbitrage Model," the ralue of housing characteristics is lowered as a discount for being near negative uses. This explains the decrease in demand for housing in the neighborhood and the low housing values and contract rents. 


\section{CHAPTER IV}

\section{ASSESSMENT OF CHANGES IN SOUTH WORCESTER}

This paper reviewed the theories of the dynamics of change and applied them to the neighborhood of South Worcester. It analyzed a neighborhood which has experienced changes in its residential environment. This chapter concludes the assessment of these neighborhood changes with a theoretical understanding of the dynamics occurring in this neighborhood. It applies the theory and concepts considered in Chapter I which best explain the neighborhood change dynamics occurring in South Worcester.

As detailed in the previous chapter, the residential amenities have altered during the past twenty years to weaken the desirability of the neighborhood. Changes in structural characteristics of units and in locational attributes added to environmental diseconomies considered by households in estimates of future property value. Aging structures, construction of a major highway and the expansion of non-residential land uses have had a negative impact on the residential environment in this neighborhood.

The theory which best explains the neighborhood change dynamics in South Worcester is the "Arbitrage Model of Transition." This theory focuses on the effect that external factors in and around the neighborhood have on the housing 
values and the dynamics of change. Its concept of households preferring and ranking "housing bundles" in terms of a dwelling unit's collective physical and neighborhood characteristics developed from the "Succession and Filtering" theory's consideration of aging structures, Hurd's concept of external influence on property values and Bailey's studies of residential segregation by population characteristics. There are three concepts particular to the "Arbitrage Model" which best explain the neighborhood dynamics in South worcester. They are the arbitrage process by which the housing supply moves from one market to another, its consideration of future expectations of change and its interpretation of the filtering process. These factors separate it from the several theories considered in Chapter I. Their application make it possible to understand the dynamics occurring in South Worcester.

\section{ARBITRAGE PROCESS}

According to the "Arbitrage Model," households, in a competetive market, act in a market arena within the parameters of their tastes and income level and the character of the housing supply which is best suited to these. As discussed in Chapter $I$, the arbitrage process of this theory is the means by which the housing supply moves from one neighborhood to another or by a change in the housing bundie to such a degree that it serves a new and different clientele. The latter is occurring in the South worcester neighborhood 8 its itructures age and the neighborhood 
characteristics change.

Aging Structures

As found in Chapter II, the structures in South Worcester are aging. Nearly ninety per cent of the housing units are in structures built in 1939 or earlier making them over forty-one years old. The value of these dwelling units are below the city arerage with a median house value of $\$ 17,000$ $(\$ 39,000$, city) and a median contract rent of $\$ 118$ (\$166, city). In addition, some units in South worcester have been torn down. Their land has been left vacant or has been absorbed into neighboring land uses.

According to the "Arbitrage Model," the structural characteristics of a dwelling unit are considered by households in terms of soundness and modernity. A higher preference rank is given to those units with higher degrees of soundness and modernity; a lower ranking given to those with less. Older units require more repairs for upkeep. This maintenance is expensive, but is necessary to extend the life of the unit. If it is not done, the structure continues to deteriorate with age, thereby losing more soundness. In addition to losing soundness, aging structures have less to offer for housing services; thus, their modernity depreciates with age.

The value of these aging structures, which are losing soundness and modernity, decreases as the households rank them lower on their preference scale. The units become desirable only to a lower-income clientele whose tastes they 
satisfy within the bounds of their income level. As the cycle continues, the maintenance which is required is left undone causing the structure to deteriorate and depreciate further, fulfilling the needs of ever lower-income level households. Eventually they lose value completely and are torn down to make room for another structure or another land use.

This is the theoretical understanding of the impact which aging structures have on a residential environment. It partially explains the lower housing values and changing neighborhood characteristics in South worcester. However, there are other factors to consider before the arbitrage process of the market dynamics in this neighborhood can be fully described.

Locational Attributes

During the 1960's, there were two events which influenced the process of change in the South worcester neighborhood environment. They were the construction of the expressway, Route 290, and a change in the zoning classifications. As described in Chapter III, both of these actions had a negative impact on the residential environment in the neighborhood.

The expressway was constructed in the early 1960's. One street with three structures was eliminated and several other structures in the areas nearby were absorbed into contiguous land uses, most of which were commercial or industrial. The presence of Route 290 also added environmental diseconomies 
to the residential environment of the nearby housing units. While easier access to a major transportation route is a benefit, the highway is a negative externality for a housing environment in terms of the nuisance of the vehicular noise It generates, the additional air pollution from the rehicles and the safety hazard from increased traffic travelling through the neighborhood accessing the expressway. These factors have a negative environmental impact on the residential amenities in the area.

According to the "Arbitrage Model," the value of a dwelling unit is lowered by households as a discount for the unit's location near diseconomies, factors which negatively impact the residential environment of a unit. Therefore, the dwelling units in South worcester are ranked lower or discounted for the traffic, noise and air pollution as diseconomies from Route 290. This is an additional factor in the low housing values as an indicator of lower preference ranking of a housing bundle by households of the housing bundle in South worcester.

Also introduced during the same time period was a revised zoning plan. While most areas are zoned according to existing land uses, there are areas in South worcester where the residential land use is a non-conforming use in an area zoned for heavy manufacturing. Chapter III considered two such areas. In these areas zoned MG 2.0 and 4.0 , the land use is residential with manufacturing uses bordering it. There is no buffer zone of MI, Iight Industry, between 
the incompatible land uses to reduce the impact of the negative effects as was done elsewhere. These MG zones are areas which are inappropriately zoned for the existing residential land use.

The MG 2.0 and MG 4.0 zoning classifications permit the expansion of the industries surrounding the residential neighborhood. Examples of such expansions cited in Chapter III are the expansion of a wholesale and retail fence business and the expansion of the Babco Metal Company, an industrial scrap metal company. As these non-residential land uses expand, the field of influence of the negative externalities encompasses more residential area. The deteriorating $D$ Street area discussed in Chapter III is an example. This area is near unkempt vacant lots owned by Babco Metal Company and the city. Also nearby are a trucking and salvage company and a railroad.

The purpose of zoning is to eliminate negative external effects by separating incompatible land uses, such as the residential and manufacturing land uses. A manufacturing classification allows uses which have negative effects on residential land uses. It permits heary manufacturing which is a risual nuisance and has such negative externalities as noise and air pollution, higher volume of traffic and the use of heavier vehicles through area streets. These factors are not conducive to the quiet, clean, safe environment which are sought after qualities in a residential area. Over the long term, zoning for more intensive uses is 
detrimental to the residential environment. As the more intense use spreads, the property values of the residences decrease due to the diseconomies of being located near a non-residential land use.

The "Arbitrage Model" would contend that the negative externalities of the manufacturing land use alters the housing bundle considered by households in a locational decision. Households consider them to be diseconomies and subsequently place a lower preference rank on a unit. The value of the unit is discounted for being near the negative uses.

\section{Summary}

Route 290 affords the manufacturing interests in South Worcester locations which are near main transportation routes for easy accessibility for market capacity and transportation needs. The MG zoning classification permits their existence and expansion in this residential area. In addition to this impact on the residential uses within the MG zone, as the industrial use spreads so does its field of negative impact. The residential ambience is affected as the structures age and the negative environmental factors of noise and air pollution and visual diseconomies spill over to affect the housing bundles of units in South Worcester. As the housing bundle changes in this manner, the arbitrage process of the "Arbitrage Model" is taking place in South worcester. The housing bundle is changing to serve a new and different clientele. 
PUTURE EXPECTATIONS

The theoretical explanation of the dynamics occurring in South Worcester is enhanced with the application of the concept of households' future expectations of the status of their housing bundle. According to the "Arbitrage Model," households make locational decisions using future expectations of the values of their property. They rank a unit according to their preferences for a housing bundle within their taste and income parameters. Continuously reassessing, households adjust the value of their property based on future expectations of the structural and neighborhood characteristics of their unit. Any expected changes influence the preference ranking, subsequently the value, of their housing bundle to be used in a locational decision.

As discussed earlier, households consider the structural characteristics of a dwelling unit for soundness and modernity. The structures in South worcester are aging. Households in this neighborhood base their future estimates of the value of this portion of their housing bundle on units with aging structural characteristics. Therefore, the future estimated value of these structures decreases as households expect the units to require more maintenance and upkeep.

The future expectations regarding locational attributes are not as predictable and estimates are made in an uncertain environment. Therefore, while reassessing their housing bundle, households are very sensitive to factors they perceive as a sign of change in the neighborhood. External 
events may suggest an upcoming change in the housing bundle. For example, new housing, commercial development or shifts in local government policy can alter future expectations of the value of a housing bundle. They add new elements to the housing bundle which are considered by households in the preference ranking process and the subsequent locational decision.

As detailed in Chapter III, South Worcester experienced increasing vacancy rates and a decreasing housing supply during the 1960's and the 1970's. During the 1960's, this neighborhood witnessed two events which influenced these changes in the residential environment--the construction of Route 290 and the revision of the zoning classifications within the neighborhood. Applying the concept of future expectations, households anticipating these external events assessed their property based on changes they expected to affect their housing bundle. Route 290, as a boundary of South Worcester, provides easier access to a major transportation route. As such it is a benefit to a housing bundle. Also considered by households, though, were the negative environmental externalities of increased vehicular noise, additional air pollution and an increased safety hazard from vehicular traffic accessing the expressway. These negative environmental factors foster an expectation for a decrease in the value of the housing bundle.

The revised zoning plan also influenced future expectations of changes in the housing bundles. Zoning as a 
policy increases expectations of future external diseconomies in the residential environment if non-residential activities are permitted. Accordingly, the manufacturing zoning classification in South Worcester increased the expectations of non-residential activities and their associated traffic and visual diseconomies. These non-residential activities and their negative externalities detract from the neighborhood's residential amenities. As a result, South worcester households discounted their future property values in their reassessment process based on expectations for manufacturing and related activities and their associated and generated traffic and visual diseconomies.

Considering the structural and environmental changes, South worcester households expected alterations which influenced their preference ranking for their housing bundles. Housekolds bad expectations of discounting property values and lowering the preference ranking as structural and neighborhood environmental characteristics change. These factors are considered by households when making locational decisions. According to the "Arbitrage Model," as long as future estimates satisfy households in terms of tastes and income parameters they stay; however, households that are dissatisfied consider a move or experience a decrease in property values.

\section{PIITERING}

The focus of the filtering process, as dascribed in the 
"Arbitrage Model," is the household, not the dwelling unit. In this theory, the welfare of a household is based on their preferences. As long as the households feel they have improved their situation, without a change in income and tastes, they have effectively "filtered up." Conversely, if they feel they have a less desirable housing bundle, they have "filtered down." Hence, it is the household, not the dwelling unit which is the participant in the filtering process. Key to this concept is the implication that this process can occur even if the household does not move. A household making a locational change to a different housing bundle is involved in an active filtering process while a household experiencing a change in its housing bundle without a move experiences passive filtering.

The filtering process experienced by households in South worcester is due to changes in the neighborhood environment. The loss of soundness and modernity as the agiñ structures are not maintained adequately and the impact of the negative externalities from the expressway and the expanding non-residential uses change the housing bundle for the households. As they perceive these changes taking place, they lower the preference rank for their housing bundle. Without a change in income or tastes, the households experience a filtering down to a less desirable bundle. In a locational decision, housebolds may elect to move to "filter up" to a more preferred housing bundle. However, some households as described in Chapter III are unable to move 
for economic or emotional reasons. They stay and become a "trapped population" as they "filter down" on their preference scale.

The three concepts discussed above are interrelated and work together to explain the neighborhood change dynamics in South Worcester. The interplay of the factors at work are also tenuous since they rely on the tastes and preferences of the households. Integral to the dynamics of change in South worcester is the perceptions of households regarding the impact of the external events and their influence on the housing bundle.

The arbitrage process in South Worcester occurs as the housing bundle is altered by the changes in the residential environment to be used by a new clientele. The process takes place as households have future expectations of changes and estimate a lower preference rank and discount their property value based on perceived negative externalities. Their locational decisions are made in this arena to avoid a lower ranking on their preferance scale. As they experience these discounts in the property value, they "filter down" to a less desirable housing bundle. As households move to "filter up" to a more preferred housing bundle, they are making room for a new clientele whose preferences and lower income level the new housing bundle satisfies. According to the "Arbitrage Model," the characteristics of these new residents are also taken into consideration as part of the housing bundle in the reassessment process of future 
expectations. Households continue to filter up or down as they perceive a more or less desirable housing bundle and make the subsequent locational decision.

The neighborbood change dynamics in South Worcester, as understood with the "Arbitrage Model," can become cyclical in nature if no changes are made. The structures in South Worcester will continue to age and fall into disrepair without the necessary maintenance for upkeep. The preference rank of these units will become ever lower on the preference scale as they are discounted for losses in soundness and modernity. In addition, the construction of Route 290 and the manufacturing zoning classifications created a benevoient atmosphere for non-residential land uses. Easy access to Route 290 provides excellent accessibility to markets along major transportation routes for the industries which are permitted land uses in areas within the neighborhood. As these non-residential land uses expand so does their field of influence. Housing bundles in residentially zoned areas are also impacted as described in Chapter III. The area zoned RG-5 was impacted by the externalities from the land uses nearby and the expressway.

Together, the negative structural characteristics and the diseconowies from the non-residential land uses and the expressway make these housing bundles less desirable to households. Consequently, the units are ranked lower on their preference scale and are given lower property values. The lower values satisfy the preferences and income levels 
of the lower-income households. This lower available income limits the amount of repairs and upkeep on a unit continuing the loss of soundness and modernity. As these units fall into disrepair and are left vacant, non-residential land uses may move to areas once utilized by residential land uses. This eniarges their field of influence and the cycle continues until the residential land use is non-existent in the non-residentially zoned areas. The impact of the negative externalities associated with these uses and the aging process with limited maintenance will be witnessed in the housing bundles further into the residentially zoned areas as well.

\section{SUMMARY}

This study of the dynamics of neighborhood change provides a theoretical understanding of events in the neighborhood of South Worcester. The application of key concepts of the "Arbitrage Model" assesses the effects of the aging structures, the construction of Route 290 and the revised zoning plan. The residential environment of South worcester as it is considered by households making locational decisions has been altered. The residential ambience of the neighborhood has been weakened by these erents and the diseconomies associated with and generated by them. While detracting from the residential environment, the dynamics of change have also enhanced the desirability of certain areas in the neighborhood for non-residential land uses. Areas in South 
Worcester may experience further expansion of its nonresidential land uses as the housing supply changes to serve a new and different clientele. 


\section{BIBLIOGRAPHY}

Baeker, James Arnold. Social Class and Family Iife Cycle

Measures as Indicants of Lower Class Community

Perceptions. Unpublished thesis. University of Rhode Island, 1970.

Blue Book Cross Reference Directory, Worcester and Vicinity.

Plainville, MA: Cole Publications, 1980.

Community Studies Program. 1900 South Worcester Census

Sample. Assumption College. Worcester, MA, 1983.

De Gioranni, Frank F.. "Patterns of Change in Housing Market

Activity in Revitalizing Neighborhoods." Journal of the

American Planning Association. Vol. 49, No. 1, Winter, 1983, pp. 22-39.

Department of Land Use Control. Photogrammetric Map (Topographic Map). Sheets 165, 166, 176, 177. Moore Survey and Mapping Corporation. Worcester, MA, 1975.

Ervin, David E., et al. Land Use Control: Evaluating Economic and Political Effects. Cambridge: Ballinger Publishing Company, 1977.

Finsterbusch, Kurt and Greisman, H. C.. "Identifying the Quality Neighborhood." Journal of Urban Analysis. Vol. 7, February, 1983, pp. 117-133. 
Gale, Dennis E.. "Middle Class Resettlement in Older Urban Neigbborhoods." Journal of the American Planning Association. July, 1979, Vol. 45, No. 3, pp. 293-304. Goetze, Rolf. Building Neighborhood Confidence. Cambridge, MA: Ballinger Publishing Company, 1976. Goldman, Mark. "Buffalo's Black Rock: A Neighborhood and the City." Neighborhoods in Urban America. Edited by Ronald H. Bayor. New York: National University Publications Kennikat Press, 1982. Gordon, Joel I.. The Three-Decker and Its Environment. Unpublished Thesis. Worcester Polytechnic Institute, 1967.

Jacobs, Jane. The Death and Iife of Great American Cities. New York: Random House, Inc., 1961. Keller, Suzanne. The Urban Neighborhood. New York: Random House, 1968.

Leven, Charles I., Iittle, James T., Nourse, Hugh $0 .$, and Read, R. B.. Neighborhood Change: Lessons in the Dynamics of Urban Decay. New York: Praeger Publishers, Inc., 1976.

Mieszkowski, Peter. "Notes on the Economic Effects of LandUse Regulation." Institut International de Finances Publique. XXVIII Session Confreds de New York, 1972,. pp. 252-273.

Netzer, Dick. Economics and Urban Problems. 2nd edition. New York: Basic Books, Inc., 1974. 
Office of Planning and Community Development. Existing Land Use. Worcester, MA, December, 1973. Peterson, James. "Revenues as Indicators of Neighborhood Stability." Benjamin Goldstein and Ross Davis, eds. Neighborhood in the Urban Economy. Lexington, MA: Lexington Books, 1977.

Poplin, Dennis E.. Communities: A Survey of Theories and Methods of Research. 2nd edition. New York: MacMillan Publillan Publishing Company, 1979.

R. I. Polk and Company. Polk Survey, 1977-1979. Office of Planning and Comwunity Development, Worcester, MA, 1979. House Directorles. Worcester, MA., 1960, 1966, 1970, 1975, 1979.

Solowon, Arthur P. and Vandell, Kerry D.." Alternative Perspectires on_Neighborhood Decline." Journal of the American Planning Association. Vol. 48, No. 1, Winter, 1982, pp. 81-98.

U.S. Department of Commerce. U.S. Census, Sumary Tract Data, 1980. Central Massachusetts Regional Planning Commission, 1980.

Worcester Planning Department. Sketch Plan for Worcester, Massachusetts. Worcester, MA, May, 1963. 